\title{
A METALURGIA CASAL, 1964-1974 ELEMENTOS PARA UMA CULTURA DE EMPRESA
}

\author{
Manuel Ferreira Rodrigues *
}

\section{INTRODUÇÃO}

Sob os efeitos da internacionalização, da multinacionalização e, mais recentemente, da globalização — fenómenos conexos mas distintos -, assiste-se, ora com perplexidade, ora com euforia, à derrocada do Estado-Providência e do mundo criado sobre os seus fundamentos políticos, económicos, sociais e culturais. Na sua desintegração, o Megaestado $^{1}$ arrasta consigo, também, a teoria clássica internacional. De facto, «não é exagero dizer-se que se está hoje perante um quase vazio teórico das relações económicas internacionais. A teoria assentou, desde Adam Smith a David e Ricardo ou, mesmo, a Samuelson e, praticamente até aos nossos dias, no pressuposto da imobilidade dos factores produtivos - terra, trabalho, capital e tecnologia» ${ }^{2}$.

A crescente mobilidade dos factores produtivos, a emergência de um novo paradigma tecnoeconómico ${ }^{3} \mathrm{e}$ o fracasso das experiências políticas dos utopismos igualitaristas (com o concomitante regresso do pragmatismo neodarwinista) transmudaram a Empresa e o Estado, fazendo com que a competição entre empresas se sobrepusesse à competição entre Estados, tornando, até, a competição, entre estes, 'prisioneira' dos interesses estratégicos daquelas: «as empresas, e não os países, estão na linha da frente da competição internacional» ${ }^{4}$.

Os três motores da globalização - liberalização, privatização e desregulamentação - provaram que as empresas são «organizações suficientemente flexíveis para se adaptarem às condições de mudança», que «o 'caminho para o global' é de longe mais fácil para as empresas que para os governos» ${ }^{5}$. Assim, Estado e Empresas «entraram numa nova dinâmica de aliança» em que «a empresa está em vias de tornar-se a organização 'reguladora' da economia mundial, com o apoio dos Estados 'locais'»6. Desta forma, «as empresas adquirem, gradualmente, uma legitimidade histórica e um papel social que se aproximam, em muitos aspectos, da legitimidade e do papel próprios do Estado » ${ }^{7}$. As empresas tendem a ser

* Instituto Superior de Ciências da Informação e da Administração (ISCIA), Aveiro. 
vistas, não apenas espaços de produção de bens e serviços, mas também espaços de produção social e cultural, ou seja, espaços de subjectividade, de identidade e integração para indivíduos, e indivíduos e grupos ${ }^{8}$.

Portanto, independentemente dos limites da competição em si mesma ${ }^{9}$, como das enormes fragilidades da estrutura empresarial das duas últimas décadas ${ }^{10}$, independentemente das considerações sobre a natureza do Sistema Mundial emergente, como da justeza das análises prospectivas (desencontradas) dos mais reputados gurus do "management", a verdade é que, na actual configuração de globalização triádica ${ }^{11}$, a Empresa (especialmente a que tem uma abordagem global da estratégia) se tornou um espaço privilegiado para a compreensão desse mundo cada vez mais relacional, acentrado e ideologicamente 'neutro'.

É neste contexto que se enquadra o diversificado e elevado número de estudos, programas e publicações específicas sobre a Empresa, que abordam a flexibilidade e complexidade da sua estrutura multímoda e contribuem para a mitificação da empresa e do espírito empresarial, expressão evidente de uma das mais poderosas ideologias deste final de século ${ }^{12}$.

Também o já significativo número de histórias de empresas e de empresários, publicadas em vários países, sendo correlato do inusitado e recente interesse da História pela Empresa, é, antes de mais, parte integrante desse movimento social e pluridisciplinar em torno do microcosmos empresarial.

Depois de uma fase, situada entre os anos Trinta e os anos Setenta, ainda caracterizada por um relativo divórcio (ou aversão) entre o mundo da Empresa e a História - que Louis Bergeron apelidou de pré-cientifica ${ }^{13}$ - a Empresa tem vindo a adquirir um estatuto de instituição central, na análise e compreensão do mundo contemporâneo.

Apesar dos equívocos e ressentimentos (mútuos), o diálogo História/Empresa está lançado. Da parte da Empresa, como da parte da História, temos assistido a variações de uma significativa mudança de atitudes. Portanto, a História veria na Empresa um espaço privilegiado de análise social, económica, política e cultural, uma célula-síntese de fenómenos locais e globais. Por seu lado, os estudos históricos, funcionando «como uma espécie de reservatório de ideias, técnicas e problemáticas» ${ }^{14}$, permitiriam a análise de situações, conceitos e padrões de solução há muito descartados pelas conjunturas, com vista à solução dos problemas actuais. «Numa altura em que se sucedem as reestruturações e as fusões de empresas, num tempo de mudanças rápidas, nas estratégias, nos mercados, nos produtos e nas tecnologias, a investigação histórica poderá ser o instrumento necessário à ameaça de amnésia nas organizações» ${ }^{15}$, porque, como sublinha Félix Torres, «uma empresa não renasce todos os dias: a continuidade é a sua grande força. Procura na memória a sua identidade e os princípios da sua acção: tudo isso contribui para formar uma cultura de empresa» ${ }^{16}$. 
Mercê da valorização da relação História/Empresa, a consagrada expressão história das empresas tem vindo a ser substituída por outras, mais sedutoras, como história na empresa e história aplicada à empresa ${ }^{17}$. Estas expressões da nova história da empresa, mais do que simples variações terminológicas, enunciam uma mudança ainda em busca de sentido: a investigação deixa de se restringir ao passado, visa interligar passado, presente e futuro, incluindo áreas 'novas' como «a formação dos recursos humanos, o "marketing", a publicidade, a concorrência, a auto-imagem e a imagem a transmitir para o exterior, a política de gestão, a tomada de decisões e a definição de estratégias» ${ }^{18}$.

Poderíamos dizer, pois, que essas expressões testemunham uma importante mudança operada no sentido da cumplicidade História/Empresa. Na verdade, a forma que assume essa mudança e essa relação reitera alguns dos vectores da evolução recente da investigação científica, que tende «a aproximar mais a ciência da tecnologia [...], o que explica, entre outras razões, que o ambiente universitário não seja já o local exclusivo da investigação fundamental (os laboratórios industriais tornaram-se, eles também, centros de descobertas 'fundamentais' [...]), ao mesmo tempo que os universitários tendem a associar-se cada vez mais a firmas industriais em programas comuns de investigação fundamental» ${ }^{19}$.

Mas as dificuldades do diálogo história/empresa assentam precisamente na natureza dessa cumplicidade, nos seus pressupostos ideológicos, como nas suas implicações metodológicas e epistemológicas. Essas dificuldades parecem ser expressão da oposição ciência/tecnologia, compreensão/transformação. De que modo é que os estudos de história na empresa não serão instrumentos de legitimação dos novos discursos ideológicos sobre as empresas? Irá a História servir a Empresa como, no passado, serviu as estratégias de poder do Estado? Como poderá a história na empresa explicar/transformar sem instrumentalizar?

A cultura «assumiu um papel relevante nos estudos de mudança organizacional, servindo como um dos suportes das Teorias de DO (Desenvolvimento Organizacional). Mais modernamente, o conceito assumiu de novo importância, em consequência de estudos que tiveram repercussão universal, como In Search of Excellence, ou o deslumbramento perante as técnicas de gestão japonesas, as quais deram origem a uma particular atenção à cultura corporativa e ao aparecimento de obras de divulgação sobre cultura empresarial» ${ }^{20}$.

Mas, desde que a cultura de empresa entrou no léxico do "management", o seu significado e funções têm variado com as 'modas' da gestão, a diversa natureza dos problemas a resolver e a ideologia dos seus mentores. Assente na crença - imposta pela ineficácia dos velhos modelos de gestão, ou pela necessidade de os travestir - de que a cultura constitui um factor de sucesso da empresa, tem prevalecido uma visão estreita do conceito, mais próxima da manipulação do que da personalização, ou mesmo daquilo a que Tom Peters chama empresarialização. Recentemente, não sem hesitações, alguns autores têm defen- 
dido que «a cultura de empresa fornece elementos e critérios para análise do funcionamento da organização que geralmente os modelos universais e contingenciais não conseguem identificar, na medida em que assentam sobre uma visão óptima e não sobre uma visão do real» ${ }^{21}$.

Seja como for, «ninguém duvida hoje que a importância da história na empresa decorre da revalorização da cultura de empresa e do papel que a identidade representa, como recurso essencial para uma melhor e mais eficaz mobilização dos trabalhadores, em torno de um projecto comum. $O$ discurso histórico aparece, assim, como um dos pilares da identidade»" 22 . A empresa «"foi muitas vezes uma organização amnésica gerindo o quotidiano, deixando a história para os arquivos quando eles existiam; só o reconhecimento de que a identidade da história, desde os grandes actos fundadores que estiveram ligados à sua criação e desenvolvimento, até aos grandes momentos que acabaram por moldar um determinado estilo de vida, os seus hábitos e comportamentos, os seus mitos, os seus ritos e seus tabus" é que levou gestores e empresários a olhar a história com outros olhos» ${ }^{23}$.

Sendo assim, de que modo pode o discurso histórico responder a esta nova realidade envolvida pela metáfora cultural? Para A. Rafael Amaro, o discurso histórico a) «ajuda a interpretar o tempo, ligando o passado ao presente e o presente ao passado, numa interacção constante, sem perder de vista o futuro»; $b$ ) «um maior e melhor conhecimento da história das empresas - dos seus fundadores, das suas crises e dos seus sucessos, da evolução e das mudanças tecnológicas, etc. - acaba sempre por reforçar o sentimento de pertença à organização»; $c$ ) o discurso histórico, «funcionando como qualquer ideologia, estrutura a identidade da organização ao mesmo tempo que ajuda a dar um sentido à acção colectiva ${ }^{24}$.

O história da/na empresa poderia, assim, ajudar a 'ler' a cultura da empresa, entendida como um factor de mudança, «um sistema cibernético» ${ }^{25}$, ou mesmo como um sistema de valores identitários, de padrões de comportamento fundados no percurso colectivo dos membros de uma empresa que «são o seu principal activo e não o seu principal passivo» ${ }^{26}$.

Apesar do grande apoio encontrado na Metalurgia Casal, este trabalho não resulta de um interesse da Empresa pela História; à sua elaboração presidiu um explícito interesse da História pela Empresa. $\mathrm{Na}$ forma como se apresenta este estudo, mais não é, ainda, do que um primeiro tentame de abordagem e reflexão sobre alguns aspectos da formação e da primeira década de existência desta fábrica de motores e motorizadas.

Com o fim da 2. a Guerra Mundial, ultrapassadas algumas das hesitações sobre a forma e o ritmo que se lhe poderia imprimir, o governo português fez do programa da industrialização - consignado na Lei do Fomento e Reorganização Industrial (Lei n..$^{\circ} 2005$, de 1945) e na Linha de Rumo, do Eng. J. N. Ferreira Dias 
Júnior - um dos elementos centrais da sua estratégia económica ${ }^{27}$. Essa política industrialista, que dotou o «nosso país de uma estrutura e duma mentalidade industrial anteriormente inexistente», não teve alternativas ${ }^{28}$.

Com a década de 50 - quando a indústria constituía já o sector mais dinâmico da sociedade -, assiste-se ao lançamento da política dos 'planos de fomento'. Considerado um «compasso de espera, de certa maneira, ponte entre o Portugal essencialmente agrícola e o Portugal industrializado, a principal novidade da proposta do I Plano de Fomento (1953-58), no que se refere à indústria, para além da modéstia dos objectivos, era o apelo feito à iniciativa privada, a quem caberia reactivar o processo de industrialização, deixando o Estado proporcionar as condições necessárias à sua efectivação». Esse apelo seria repetido anos depois, pelo ministro da Economia, Ulisses Cortês, no II Congresso dos Economistas e da Indústria Portuguesa (1957): «A acção estatal deve consistir menos em investir directamente do que em traçar orientações, propor finalidades, criar estimulantes fiscais, orientar o crédito e instituir as condições indirectas, quer económicas e financeiras, quer técnicas e culturais, que propiciem o desenvolvimento das iniciativas e o esforço criador dos particulares $»^{29}$.

Apesar de tudo, a opção que conduziria à eleição do sector secundário como prioritário para o arranque desenvolvimentista só ocorreu durante a vigência do II Plano de Fomento (1957-1964). A expansão industrial assentava ainda em dois estímulos principais: a reserva de mercados (externamente com a política aduaneira e internamente com o condicionamento industrial) e o baixo preço dos factores produtivos (de mão-de-obra e capital, especialmente) ${ }^{30}$.

A partir da década de 60 tudo iria ser diferente. Um variado (e contraditório) conjunto de fenómenos e acontecimentos impuseram mudanças irreversíveis em todos os domínios, possibilitando aliviar tensões internas e abrir caminho a uma nova estratégia. Em 1960, dá-se a decisiva adesão à EFTA; são criados o Instituto Nacional de Investigação Industrial e o Banco de Fomento Nacional. Em 1963-64, inicia-se outro ponto alto da emigração portuguesa que se prolongaria até 1973-74; o êxodo rural é absorvido pela emigração e pela explosão urbana; acentua-se o fenómeno de polarização social (menos patrões, maiores empresas, muito mais operários por empresa, em geral); em 1964, realiza-se o Inquérito Industrial e prossegue a concretização do projecto do 'Mercado Comum Português', enquanto decorrem as guerras coloniais, desde 1961; em 1965, é aprovado o Plano Intercalar de Fomento (1965-67), seguido, depois, pelo III Plano de Fomento; em Janeiro de 1966 entra em vigor o novo regime de Condicionamento Industrial, fechando-se um ciclo iniciado em 1948; em 1968, o governo muda de direcção; e em 1972, seria celebrado um acordo comercial celebrado com a CEE. Todos estes acontecimentos, a que se deve juntar a liberalização do investimento estrangeiro, aceleraram o processo de abertura da economia portuguesa ${ }^{31}$. 
2. O EMPRESÁRIO - DO COMERCIANTE AO INDUSTRIAL, 1945-1964

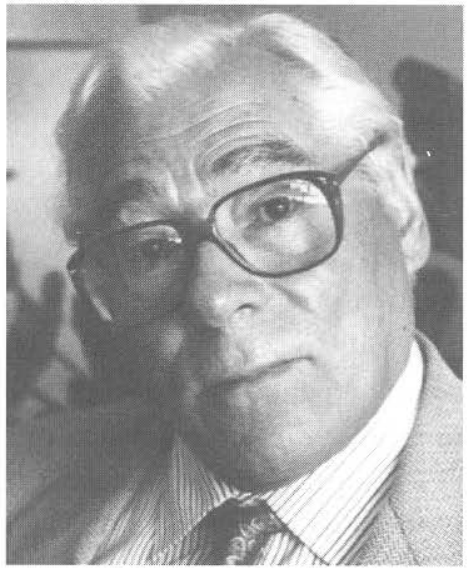

Fig. 1 - JOÃO CASAL, 1994 (Foto MFR)

Com as condicionantes do tempo de mudança acima evocado, a Metalurgia Casal está intimamente ligada à vida do seu fundador, João Francisco do Casal. Especialmente entre 1945 e 1964, o jovem empresário adquire um profundo conhecimento do mundo condicionado do Estado Novo e a compreensão bastante dos mecanismos da economia aberta. Durante esse período, visitou inúmeras exposições e fábricas de bicicletas, motorizadas, automóveis e de componentes, na Alemanha, Itália e França. O nascimento da Metalurgia Casal constitui, assim, o epílogo de uma grande experiência que este empresário aveirense adquiriu, durante muitos anos, nos sectores de motores e motorizadas. Só esse capital de conhecimentos permite compreender, em muitos dos seus aspectos, a natureza e a dimensão do projecto que o tornou conhecido.

Filho e neto de proprietários, agricultores e comerciantes de gado, João Francisco do Casal nasceu, em 1922, no lugar de Bonsucesso, freguesia de Aradas, nos arredores de Aveiro. O pai, imigrado no Brasil durante dez anos (onde teve uma fábrica de biscoitos), regressou em 1918, dois anos antes de casar.

\section{GENEALOGIA SIMPLIFICADA DE JOÃO FRANCISCO DO CASAL}

$\begin{array}{cc}\text { João Francisco do Casal } & \text { Domingos Simões Morgado } \\ \text { Lavrador, Bonsucesso } & \text { Lavrador, Verdemilho } \\ \text { Teresa Ferreira Borralho } & \text { Maria de Jesus Parca } \\ \text { Lavradora, S. Bernardo } & \text { Lavradora, Bonsucesso }\end{array}$

João Francisco do Casal Teresa Ferreira Borralho

Lavradora, S. Bernardo

José Maria Pata
Lavrador, Gafanha da Nazaré
Rosália de Jesus
Doméstica, Gafanha da Nazaré

João Gonçalves Maia Lavrador, Aradas Rosa Marinheira Lavradora, Aradas

\section{Júlio Francisco do Casal (1883-1963) \\ Lavrador, Verdemilho \\ Silvina Simões Morgado (1895-1987)}

Lavradora, Bonsucesso
Manuel Maria Pata (1885-1964)

Agricultor, Gafanha da Nazaré

Maria Gonçalves Maia (1895-1940) Agricultora, Aradas

Maria Morgado do Casal (1920-1940)

Manuel Francisco do Casal (1921)

João Francisco do Casal (1922) c. c. Rosa Gonçalves Pata (1922)

Domingos Morgado do Casal (1927)

Conceição Morgado do Casal (1929)

Maria de Lurdes M. do Casal (1937) 
Depois da escola primária, frequentou o ensino comercial e aprendeu Francês, num estabelecimento de ensino particular, no lugar de Quintãs, da mesma freguesia. Seguidamente, foi colocado, por concurso, como factor dos caminhos-de-ferro, em Peso da Régua, donde sai, em 1945, a convite de António Marabuto, com quem fundaria a sociedade Marabuto, Casal \& Madail. L. ${ }^{\text {da }}$ (1946), para o comércio de mercearias.

Tarefas de regularização contabilística levaram-no ao conhecimento da casa comercial Abel Pereira da Fonseca, fornecedora e cliente do seu estabelecimento. Proprietária da Sociedade Trevo, da Fábrica de Sabões, ao Beato, em Lisboa, e da Fábrica de Açúcares, em Alverca, a firma Abel Pereira da Fonseca foi importante para a formação do empresário, pela urbanidade e métodos de trabalho.

Depois dessa influência inicial, bem mais decisivo seria o contacto com os Alemães e a reconstrução alemã, no início da década de 50. Em fins de 1953, após uma passagem por Roma e Nápoles, para onde estava a exportar feijão, João Casal segue para Hamburgo, cidade muito destruída pela Guerra. Foi o primeiro de muitos outros contactos com a então República Federal da Alemanha. No regresso, em face da impossibilidade de poder realizar novos negócios no quadro da Marabuto \& C.a., L. ${ }^{\text {da }}$, abandona esta sociedade, envolvendo-se, no ano seguinte, na criação da Sociedade de Mercearias do Vouga, L. ${ }^{\text {da }}$, em Aveiro e na fundação da J. Casal.

Nesse ano ainda, volta àquele país, dessa feita para visitar a Feira de Hanôver, onde procura estabelecer contactos com empresários de vários ramos. Contacta, então, pela primeira vez, com a Zündapp-Werke $\mathrm{GmbH}$, empresa metalúrgica que procurava um representante em Portugal para os seus motores de rega, máquinas de costura e motorizadas. Essa ligação seria decisiva para a concepção da empresa, para a Escola de Formação, como para a qualidade dos produtos da Metalurgia Casal.

\section{DA J. CASAL À METALURGIA CASAL, L. DA}

Depois de ainda ter sido importador de produtos de outras fábricas, como fogões, balanças, etc., começa a importar bicicletas com motor auxiliar Zündapp. Inicialmente, não sela qualquer contrato com a fábrica de Munique. Escudado pelo BPA, João Casal ganha a confiança da empresa alemã, e vende as motorizadas Zündapp sem qualquer tipo de condições. A representação dos motores daquela marca viria mais tarde, no início de 1957, quando encomenda 2000 motores de duas velocidades.

O pedido de autorização para «exercer a montagem de bicicletas motorizadas com motores Zündapp», apresentado em Agosto de 1955, deparou com a oposição imediata da Vilarinho \& Moura L. ${ }^{\text {da }}$ e da Famel $^{32}$. A pressão dessas empresas 
surte efeito; a autorização para montar bicicletas motorizadas com motores Zündapp é-lhe negada ${ }^{33}$. Também a firma Aliança Velocipédica da Bairrada, L.da, de Mogofores, viu negada, nessa altura, a pretensão de «proceder à montagem de motores Zündapp de pequena cilindrada» ${ }^{34}$. Só bem mais tarde, em 1962, a J. Casal conseguiria o alvará «para uma oficina de reparação e afinação de bicicletas motorizadas com posto de soldadura oxiacetilénica» ${ }^{35}$.

Por forma o contornar os obstáculos à obtenção de licenças de importação, a J. Casal recebe os motores desmontados, fabrica alguns dos seus componentes (como os carretos), monta-os, vende-os e repara-os. Também o fabrico de tubos de escape e outros componentes das motorizadas se explica pelas mesmas razões.

Para assegurar o seu escoamento no mercado nacional, João Francisco do Casal cria uma estrutura de distribuição. $O$ abastecimento da região centro era assegurado pela própria J. Casal; a pensar na zona sul cria, em 1956, um armazém, em Lisboa. Para a representação daquela marca, no Norte do País, funda, com o Dr. Amândio Pereira Simões, no início de 1957, a sociedade comercial Simões \& Casal. Esta estrutura seria emalhada nos interesses de uma rede de empresas de montagem de motorizadas, de armazenistas e revendedores.

Em 1959 tenta, sem sucesso, criar uma fábrica de bicicletas, com tecnologia estrangeira, pois a «bicicleta portuguesa era muito rudimentar, muito primitiva» ${ }^{36}$. Dessa vez, procurou reunir retalhistas e armazenistas de todo o País para criar uma fábrica de bicicletas e, «paralelamente, uma de motorizadas. Assim, Portugal podia deixar de ser um país importador para ser um país exportador» ${ }^{37}$. Mais tarde, referindo-se a essa tentativa, diria: «na qualidade de importador de produtos estrangeiros, levei a efeito, na União dos Grémios de Coimbra, uma reunião de todos os industriais e comerciantes dos ramos do ciclismo a pedal e do ciclismo motorizado, com o fim de constituir uma empresa dimensionada e moderna, como aquelas que tinha visto lá fora. Dessa reunião nada resultou, porém, como já previa o malogro, a caminho de Coimbra, ia dizendo para comigo: 'se não quiserem, irei só...'» ${ }^{38}$.

Dois anos depois, em 1961, João Casal funda, com dois irmãos e um primo, a empresa Casal Irmãos \& C. ${ }^{a}$ (hoje Veículos Casal, L ${ }^{\text {da) }}$. Esta empresa comprava motores à J. Casal, montava-os nos quadros e demais equipamento adquirido à «Vilar» (Vilarinho \& Moura, L. ${ }^{\mathrm{da}}$ ), cria a sua própria marca - a Motosal - e vende as motorizadas em todo o País ${ }^{39}$.

Tendo começado como representante de produtos de "ménage", a J. Casal, com duas dezenas de trabalhadores, acaba por tornar-se uma unidade de montagem, reparação e venda de motores e motorizadas Zündapp. A actividade da J. Casal trouxe, obviamente, alguma perturbação ao sector. Escudadas nas disposições do Condicionamento Industrial, outras empresas opõem-se à introdução de altera110 ções e melhorias que pudessem pôr em causa a sua sobrevivência. 
Em 3 de Outubro de 1963, João Casal pede autorização para «instalar, nas imediações de Aveiro, uma unidade industrial para o fabrico de carretos para motores ${ }^{40}$. Esse pedido, publicado no Boletim da Direcção Geral dos Serviços Industriais, é contestado pela Fábrica de Produtos Metálicos, L. ${ }^{\text {da }}$ — Famel, de Águeda, pela empresa Motores Alma, L. ${ }^{\text {da }}$, de Gaia, pela empresa António Peixoto, L. da , de Braga, em separado, e pela Empresa Ciclista Miralago, L. ${ }^{\text {da }}$ e Rufino de Almeida, em conjunto $^{41}$.

Em finais de 1963, João Casal reúne as pessoas com quem contava para o estabelecimento de uma firma diferente, nos seus objectivos, da J. Casal, pois, «se tudo corresse bem, a Metalurgia Casal seria o produtor e a J. Casal o distribuidor» ${ }^{42}$.

\section{QUADRO I}

METALURGIA CASAL, L. ${ }^{\text {DA }}$

1963.12.26

Objecto: «Fabrico e transformação de artefactos metalúrgicos, designadamente de peças para veículos, e qualquer outro ramo da indústria».

Duração: Por tempo indeterminado, a contar de 1964.01.01.

Sede: Aveiro

Capital social $6000000 \$ 00$

\begin{tabular}{|l|l|l|c|c|}
\hline \multicolumn{1}{|c|}{ Sócios } & Profissões & Funções & \multicolumn{1}{c|}{ Quotas } & $\%$ \\
\hline João Francisco do Casal & Comerciante & Gerente & $4700000 \$ 00$ & 78,3 \\
Dr. Amândio Pereira Simões ${ }^{1}$ & Advogado & Gerente & $600000 \$ 00$ & 10 \\
Manuel Francisco do Casal $^{2}$ & Industrial & Gerente & $600000 \$ 00$ & 10 \\
António Costa Nogueira Rodrigues $^{3}$ & Industrial & Gerente & $100000 \$ 00$ & 1,7 \\
\hline
\end{tabular}

Fonte: Secretaria Notarial de Aveiro, $1 .{ }^{\circ}$ Cartório, not. Joaquim T. Silveira, liv. 121-B, fls. 32v.-35.

1. Sócio da Simões \& Casal, Porto (1957) - representante da J. Casal, no Norte do País.

2. Até aí, sócio administrador da empresa Neves \& Capote, Ílhavo (1947) — reparação de automóveis e comércio de combustíveis.

3. Encarregado da J. Casal.

Em finais de 1963 e início de 1964, pressionada pelas referidas empresas e dando cumprimento a uma política de limitação dos licenciamentos - que grandes dificuldades traria aos estabelecimentos comerciais e industriais do sector —, a Direcção Geral do Comércio evoca a guerra em África e notifica o empresário aveirense das dificuldades de concessão de licenças de importação. Dias depois, 
João Casal é chamado à Secretaria de Estado da Indústria. Atendendo à «sangria de divisas imposta pela importação de produtos Zündapp», o subsecretário de Estado, José Luís Esteves da Fonseca, 'convida' João Casal a fabricar motores em Portugal $^{43}$. O responsável governamental ter-lhe-á perguntado, mesmo: «Não o deixam importar motores? É capaz de montar uma fábrica? Entenda-se lá com a sua firma, peça já o alvará, faça-o com urgência. Vamos fazer os motores em Portugal» ${ }^{44}$.

Na Memória Descritiva enviada ao governo, João Casal procura fundamentar detalhadamente as razões por que se propunha fabricar «motores para bicicletas motorizadas e "scooters" sob licença alemã». É que, sendo, desde há muito, representante do «maior e melhor fabricante de motos, "scooters" e bicicletas motorizadas», procurara reduzir a importação de veículos e aumentara a importação dos motores, «com o único propósito de incrementar a indústria nacional de ciclismo motorizado, conseguindo, assim, elevar as suas vendas para 10000 motores anuais com possibilidades de ainda mais ${ }^{45}$. Era esse significativo número de motores que justificava, em sua opinião, a instalação de uma moderna unidade de produção industrial de motores, em Portugal. Acrescentava que, para o efeito, já existiam as instalações da Metalurgia Casal, L. ${ }^{\text {da }}$ com um investimento em máquinas que orçava em cerca de $3000000 \$ 00$.

Acrescentava mais, entre outros aspectos, que o fabrico se iniciaria «com uma montagem na qual seriam incorporados $25 \%$ de produto nacional e, no decorrer do [ano seguinte], aumentar-se-ia para 50\%», que os «técnicos, planos e pessoal especializado [seriam] fornecidos pela firma alemã Zündapp-Werke». Outros parágrafos adiantam dados que testemunham a natureza de acordo firmado entre o empresário aveirense e a sua representada: "para o investimento inicial, o requerente não tem necessidade de recorrer a capitais alheios, mas se, no decorrer da fabricação, houver necessidade de investimentos superiores às suas possibilidades a Zündapp-Werke contribui com o capital necessário». Estava previsto «que as peças de grande responsabilidade técnica e que [exigissem] investimentos de rentabilidade duvidosa, [fossem] fornecidas pela Zündapp-Werke». Esta empresa previa ainda «que, para se atingir boa qualidade dos produtos, [fosse] criada uma oficina para aprendizagem, cuja instalação [custaria] aproximadamente Esc. $1000000 \$ 00 » 46$.

No seu parecer, o Grémio dos Industriais Metalúrgicos e Metalomecânicos do Sul sublinha a orientação política de substituição das importações. Atendendo ao facto de existirem «já no País três unidades que se dedicam ou estão autorizadas a proceder ao fabrico daquele tipo de motores, [o grémio era], em princípio, desfavorável ao deferimento da pretensão». No entanto, «dado que o nível e prestígio internacional da firma alemã que apoiaria o requerente, bem como o elevado número de motores Zündapp que continuam a importar-se, julga que o pedido 112 seria susceptível de merecer atenção na medida em que comprovadamente se veri- 
fique que as unidades atrás referidas se não encontrem em posição de ocorrer em quantidade e qualidade às necessidades do nosso mercado» ${ }^{47}$.

De facto, o processo correu célere. Em Fevereiro de 1964, a Metalurgia Casal, L. ${ }^{\text {da }}$ pedira, primeiro, «para ser autorizada a exercer, nas suas instalações, ainda em construção, na Estrada de Tabueira, em Esgueira, o fabrico de conta-quilómetros para veículos motorizados ${ }^{48}$. Dias depois, a Direcção Geral dos Serviços Industriais publicita o pedido de autorização da Metalurgia Casal, L. ${ }^{\text {da }}$ para «exercer, nas suas instalações [...], o fabrico de motores de combustão com cilindrada até $250 \mathrm{~cm}^{3}$, para bicicletas motorizadas e "scooters"»". Apesar da oposição imediata das empresas já referidas, o despacho ministerial foi publicado pouco tempo depois, em 1964.05.08. Sem mais, esse documento defere o pedido, nos termos supra, sublinhando o pormenor da assistência técnica da firma Zündapp Werke $G m b H^{50}$.

Porém, as condições da licença não permitem tirar ilações precipitadas sobre o papel do 'convite' do governo na criação da fábrica. Obrigando a Metalurgia Casal, $L .{ }^{\text {da }}$ a produzir pelo menos $60 \%$ das peças dos motores nos dois primeiros anos (podendo as restantes ser adquiridas à Zündapp Werke), no fim dos quais os motores seriam inteiramente de produção nacional, o governo não considerava incluído, nessa licença, «qualquer compromisso relativo a facilidades alfandegárias e protecção ao produto fabricado». Esta alínea alimentaria equívocos e apetites.

Enquanto aguardava ainda a autorização da Secretaria de Estado da Indústria, na esperança de poder continuar a fornecer motores desmontados, a empresa alemã reafirmava, em Maio de 1964: «[...] portanto, podemos contar desta maneira com a continuação dos nossos negócios para este ano ${ }^{51}$. Em 1964.06.04, já com o alvará na sua posse, João Casal firma um acordo com a empresa alemã, em Munique, no qual se comprometia comprar-lhe todas as peças não produzidas em Portugal ${ }^{52}$.

Mas João Casal bem cedo se apercebeu de que a sua representada e licenciadora apenas queria servir-se do alvará para continuar a vender os seus produtos em Portugal, sem despesas nem riscos. Nesse sentido, tentou aliciá-lo, «demonstrando inicialmente os volumosos investimentos necessários para o fabrico de toda uma gama de acessórios componentes de um motor, com os inerentes riscos, absolutamente dispensáveis se se dedicasse exclusivamente à montagem ${ }^{53}$. A Zündapp «limita, então, o número de acessórios a fabricar e de tal modo que seria muito difícil dar cumprimento às condições-base da concessão do alvará».

Como João Casal não concordava com os desígnios do fabricante alemão, que pretendia «pura e simplesmente levar as autoridades portuguesas para a concessão contínua de licenças de importação ${ }^{54}$, o divórcio vai consumar-se rapidamente. $\mathrm{O}$ empresário aveirense ainda oferece à Zündapp a possibilidade de ficar com 50\% do capital da Metalurgia Casal; propõe-lhe a «integração total do 
capital ficando a sua licenciadora com a posição de $50 \%$ a realizar», mas nem assim obteve a sua concordância ${ }^{55}$.

Entretanto, a Zündapp Werke procura contactar o secretário de Estado do Comércio através da Embaixada Alemã. Envia a Portugal um emissário, o sr. Misselwitz, que «expõe as suas pretensões à Câmara de Comércio do seu país, que o procura dissuadir a colaborar com a Metalurgia Casal» ${ }^{56}$.

João Casal pressiona o governo no sentido de impedir a consumação dos desígnios da empresa de Munique. Em Março de 1965, dirige-se à Secretaria de Estado da Indústria dizendo, nesse sentido: "Ainda não são decorridos dois anos e a empresa que assim se estruturou e ergueu é já hoje uma realidade viva que mereceu de Sua Excelência o Snr. Director Geral dos Serviços Industriais palavras de muito apreço, qualificando-a até como a maior da Península, no ramo» ${ }^{57}$. Em Outubro de 1965, o empresário aveirense une em sua defesa um bloco de cerca de uma dezena comerciantes de importadores que haviam aceitado apoiar o repto da Secretaria de Estado da Indústria de 'nacionalizar' os motores que mais se importavam ${ }^{58}$. Sabendo que o representante da Zündapp estava a contactar os principais interessados na aquisição dos seus motores em busca de um outro representante exclusivo, diziam os membros do bloco de comercialização dos motores Zündapp: «a nossa força e coesão, que levou os vossos produtos a ocupar $70 \%$ do nosso mercado no ramo, permanecerá firme nos seus princípios [...]», pelo que «futuramente não receberemos mais visitas Vossas e a Vossa correspondência, se a houver, não terá resposta e será por nós remetida à firma Casal» ${ }^{59}$.

No final de 1965, quando se aproximava a data da «nacionalização do motor», a Zündapp denuncia unilateralmente os contratos existentes com a Casal, firmando um acordo de fornecimento de 12000 motores anuais com a Fábrica de Produtos Metálicos, L.da. Famel. Esta empresa de Águeda, fundada em 1950 - e até aí representante dos motores DKW e JLO - terá chamado vários clientes a quem terá prometido entregar de imediato «o genuíno motor Zündapp totalmente de fabrico alemão», quando a Metalurgia Casal ainda tinha «alguns milhares de motores Zündapp e acessórios» ${ }^{60}$. Aliás, em 1967, as existências dos armazéns de acessórios, no centro da cidade de Aveiro e em Lisboa, ainda «eram constituídas por uma grande percentagem de acessórios da representação Zündapp» ${ }^{61}$.

Não conformado, João Francisco do Casal protesta junto do governo: «se temos sentido dificuldades em retirar da alfândega algumas centenas de quilos [sic] de aço, como poderá a Famel saltar por cima de interesses tão elevados e obter licenças de importação justamente para os motores que o governo desejou nacionalizar e que, atentos aos superiores interesses da Economia e Indústria Nacional, voluntariamente deixámos de importar?» ${ }^{62}$. E adianta um conjunto de dados sobre o significado económico deste sector para explicar o grande inte114 resse da empresa de Munique no mercado português — um volume de negócios 
que se cifrava em cerca de $250000000 \$ 00$ anuais, $50 \%$ dos quais representados pelas importações.

A Metalurgia Casal nascia, assim, com uma enorme contrariedade, «não tanto por perder a Zündapp, mas por passar a ter um concorrente que estava devidamente estruturado e alicerçado no País» ${ }^{63}$.

No entanto, a entrega da representação dos motores da empresa alemã à Famel teria outras consequências. João Casal conhecia o director técnico da Zündapp-Werke GmbH desde os anos 1957-58. As questões técnicas haviam sido tratadas, desde sempre, directamente com ele. Criou-se, de facto, um bom relacionamento entre os dois. $\mathrm{O}$ empresário aveirense solicitara à administração da Zündapp autorização para que o director técnico, Eng. Robert Erich Zipprich - que entretanto atingira a idade da reforma — , viesse para Portugal trabalhar na montagem dos motores. Inicialmente, a Zündapp não viu qualquer inconveniente nesse pedido. No entanto, levado a tomar partido no conflito entre a sua empresa e João Casal, discordando da entrega da representação dos motores à Famel, o Eng. Robert Erich Zipprich acaba por romper as relações com a empresa que dirigira e fica em Portugal a trabalhar com João Casal. Essa aliança tornou-se decisiva para a Metalurgia Casal.

\section{A METALURGIA CASAL - CRESCIMENTO E AFIRMAÇÃO}

O divórcio com a Zündapp-Werke marca o início de um ciclo novo, que compreende duas fases. Entre 1965 e 1970 são lançados os alicerces da nova empresa, sob a direcção técnica de uma equipa de alemães, dirigidos pelo Eng. Robert Erich Zipprich. Na fase que seguinte, entre 1970 e 1974, já sob a direcção de técnicos portugueses, são evidentes os esforços para dotar a empresa de estruturas sólidas para sustentar a expansão.

\subsection{O 'periodo alemão', 1965-1970}

Os trabalhos para o fabrico de motores têm início nos últimos meses de 1965; meio ano depois, dava-se início à sua produção industrial. Para suportar tal empreendimento, que mobilizou muita gente e muitos meios, houve necessidade de injectar capital na empresa.

No fim de 1965, quando a Zündapp rompe com João Francisco do Casal, é decidido aumentar o capital social, de seis mil contos - que se achava inteiramente realizado - para trinta mil contos. Essa medida acaba por conduzir à trans- 
formação da sociedade por quotas em sociedade anónima de responsabilidade limitada, decisão que seria concretizada no final do ano seguinte ${ }^{64}$.

\section{QUADRO II}

METALURGIA CASAL, S.A.R.L.

1966.12.22

Objecto: Exercício da indústria e comércio do ramo metalomecânico, e o de qualquer outro ramo não proibido por lei.

Duração: Por tempo indeterminado, a contar de 1967.01.01.

Capital social

Sede: Aveiro, à Estrada de Taboeira.

$30000000 \$ 00$

\begin{tabular}{|l|l|l|r|c|}
\hline \multicolumn{1}{|c|}{ Sócios } & Profissões & \multicolumn{1}{c|}{ Funções } & Quotas & \% \\
\hline & Industrial & Presidente & 17750 & 59,17 \\
Maão Francisco do Casal & Industrial & Administrador & 3000 & 10 \\
Manuel Francisco do Casal & Advogado & & 1500 & \multicolumn{1}{c|}{5} \\
Robert Amândio Pereira Simões & Eng. Mecânico & Administrador & 3000 & 10 \\
José de Matos Lima & Industrial & Administrador & 1500 & \multicolumn{1}{c|}{5} \\
Dr. António Fern. Rendeiro Marques & Veterinário & & 150 & 0,5 \\
Armando Adão Carneiro & Intérprete & & 100 & 0,33 \\
Dr. Domingos Fer. Afonso e Cunha & Médico & & 100 & 0,33 \\
Dr. Joaquim Henriques & Médico & & 100 & 0,33 \\
Eng. Armando Júlio Mor. de Campos & M. Aeronáutica & & 20 & 0,07 \\
\hline
\end{tabular}

Fonte: Secretaria Notarial de Aveiro, $1 .^{\circ}$ Cartório, not. Joaquim T. da Silveira, liv. 159-B, fls. 1-15.

Para a realização dos trinta mil contos, e em conformidade com a autorização do Ministério das Finanças, foram emitidas 24000 acções, no valor nominal de mil escudos cada ${ }^{65}$. Assim, e de acordo com os estatutos, o capital social ficava dividido em trinta mil acções nominativas ou ao portador, reciprocamente convertíveis, com o valor de mil escudos cada uma ${ }^{66}$. As primeiras 27200 acções, correspondentes a $90,67 \%$ do valor total, foram subscritas pelos membros da nova sociedade, no valor e proporção que o quadro mostra.

As restantes 2800 acções foram subscritas por 43 particulares e 2 empresas, a Ferreira, Irmão \& Sucessores, L. ${ }^{\text {da }}$ e a Casal, Irmãos \& Companhia. Os valores das acções subscritas oscilavam entre $5000 \$ 00$ e $200000 \$ 00$.

Em Junho de 1966, inicia-se a produção industrial do motor Casal. Poucos meses depois, saía a primeira "scooter", a Carina S 170. As dificuldades técnicas 116 com a Carina obrigaram a recorrer à banca. Mais uma vez, João Casal pôde con- 
tar com a colaboração do director do BPA, Porto, o Eng. João Meireles (genro de Cupertino de Miranda).

Apesar de considerar que, no ano de 1967, «está ainda numa fase de arranque, no campo industrial e no campo comercial, onde, quer no mercado interno, quer no mercado externo, os negócios estão a iniciar-se ${ }^{67}$, a empresa não deixava de salientar o sucesso dos esforços para marcar uma posição relevante no mercado nacional, «mesmo tendo em conta as contrariedades provenientes do regime jurídico dos velocípedes com motor e ciclomotores». Além dessas contrariedades, são referidas, como lesivas dos seus interesses, «as importações elevadas de motores e veículos», as quais levariam a empresa a tomar medidas no sentido de pressionar o governo a refrear a concessão de licenças e a recorrer à banca. Mas, como sublinhou o presidente da Mesa da Assembleia, em reunião de Março de 1968, a empresa conseguiu, apesar de tudo, «somar amortizações no valor de $14000000 \$ 00$, fazer provisões de $3450000 \$ 00$ e ainda apresentar um lucro de exercício de $3674000 \$ 00{ }^{68}$.

Esse crescimento inicial, encorajado pelo sucesso dos primeiros motores, leva a empresa a continuar os investimentos em infra-estruturas e equipamento industrial. No ano de 1967, essa rubrica registou, pois, um valor global de $6000000 \$ 00$. Foram lançados dois novos motores - o M151 e o M 148 - e uma nova motorizada - a Casal K 160.

Nesse mesmo ano, «concluíram-se os estudos, desenhos, planos e ferramentas de dois novos motores - um para velocípede, outro para atomizador agrícola - e de mais um ciclomotor», cuja produção seria iniciada em 1968.

No plano comercial, alargou-se e reestruturou-se o sistema de vendas: «iniciaram-se os estágios de mecânicos dos agentes [...], efectuaram-se constantes visitas técnicas a casas dos agentes; estabeleceram-se oficinas pelo País, de modo que toda a clientela pudesse usufruir de um sistema de cuidados após-venda».

Foi ainda em 1967 que se iniciaram os contactos para a colocação dos produtos nos mercados ultramarino e europeu, nomeadamente na Dinamarca e Holanda, tendo havido contactos com países como a Nigéria. A empresa expôs os seus produtos nas feiras de Joanesburgo e de Milão.

Mas o ano de 1967 seria financeiramente salvo pelas vendas da Carina, pesem embora as enormes dificuldades por que a empresa passou, quer pelas deficiências na sua concepção, quer ainda pela nova regulamentação do Código da Estrada, de finais de 1966.

No ano seguinte, em 1968, a Metalurgia Casal continuou a crescer e, apesar de afirmar já consolidada a sua posição no mercado (foi registado um acréscimo de $13,5 \%$, nas vendas, em relação ao ano anterior), continua a considerar-se «em fase de arranque e ampliação» ${ }^{69}$.

Fez-se o lançamento do atomizador agrícola e preparava-se um motor estacionário para ser acoplado a motobombas e outros fins. Foi lançada uma nova moto- 
rizada, a Casal K 163. Ficou pronto o protótipo da motorizada Casal K 181, que tinha como principal característica a sua estrutura posterior fundida em liga leve de alumínio. A direcção da empresa prometia, para o ano de 1969, novos motores: um motor automático de $50 \mathrm{~cm}^{3}$, e dois outros, para motociclos, de $125 \mathrm{~cm}^{3}$ e $150 \mathrm{~cm}^{3}$.

A autorização para «produzir na sua fábrica motores de explosão, para veículos, até $250 \mathrm{~cm}^{3}$, motociclos e tricarros, motores de explosão para outros fins e dispor livremente, para venda a terceiros, das jantes de alumínios que fabrica», apesar de obtida antes, é publicada apenas em $1968^{70}$. Até então, só a Famel e a Vilar é que podiam fabricar jantes de alumínio. Para o fabrico das jantes (aros) de alumínio, a empresa havia comprado equipamento completo, vindo a disputar o mercado existente para este produto.

Em 1969, a Metalurgia Casal regista um salto qualitativo: reforça a sua posição no mercado interno, enquanto «no mercado externo se registou uma aumento espectacular de $120 \%{ }^{71}$. Foi o ano do lançamento da Casal K 181 e da auspiciosa participação na Feira do Ciclo e Motociclo de Milão. Foi, também, lançado um motor estacionário de $75 \mathrm{~cm}^{3}$ e feitas as primeiras experiências com um motor de $150 \mathrm{~cm}^{3}$.

No plano financeiro, três anos após o início da produção de motores, $40 \%$ da fábrica estava amortizada ${ }^{72}$.

\subsection{O 'período português', 1970-74}

O ano de 1970 é determinante na história da empresa. Durante a primeira metade desse ano, a administração procura encontrar uma estrutura interna capaz de dar resposta aos projectos esboçados e à desejada expansão dos negócios. É nessa medida que se compreende a profunda reestruturação desse ano: «cada vez se torna mais notória a importância duma pronta e correcta informação, sobretudo para quem ocupa cargos directivos de empresas que empregam elevado número de indivíduos». São criados novos departamentos e elaborados os organigramas com definição de sectores abrangidos, âmbito, responsabilidades e poderes respectivos. São elaborados regulamentos internos e definidos os mecanismos de comunicação interna, visando optimizar custos e garantir o cumprimento dos objectivos. A política de preços e os cálculos de custos são revistos ${ }^{73}$.

Para isso, a empresa vai introduzir, pela primeira vez, uma «gestão previsional», porque «toda a gestão actual exige uma previsão dos elementos» ${ }^{74}$. Para conseguir o planeamento da sua actividade e a previsão dos resultados, era necessário reorganizar a empresa e gerir, com eficácia, a informação. É nesse contexto que se compreende a aquisição de um [mini] computador Philips P353/600, que entrar[ia] em funcionamento no mês de Setembro [de 1970]» ${ }^{75}$. Assim, «os dados 
referentes a facturação, contabilidade industrial, contabilidade geral, salários, ordenados e gestão de "stocks" e estatística», passariam a ser processados mecanograficamente.

\section{ORGANIGRAMA DA ADMINISTRAÇÃO \\ DA METALURGIA CASAL, SARL}

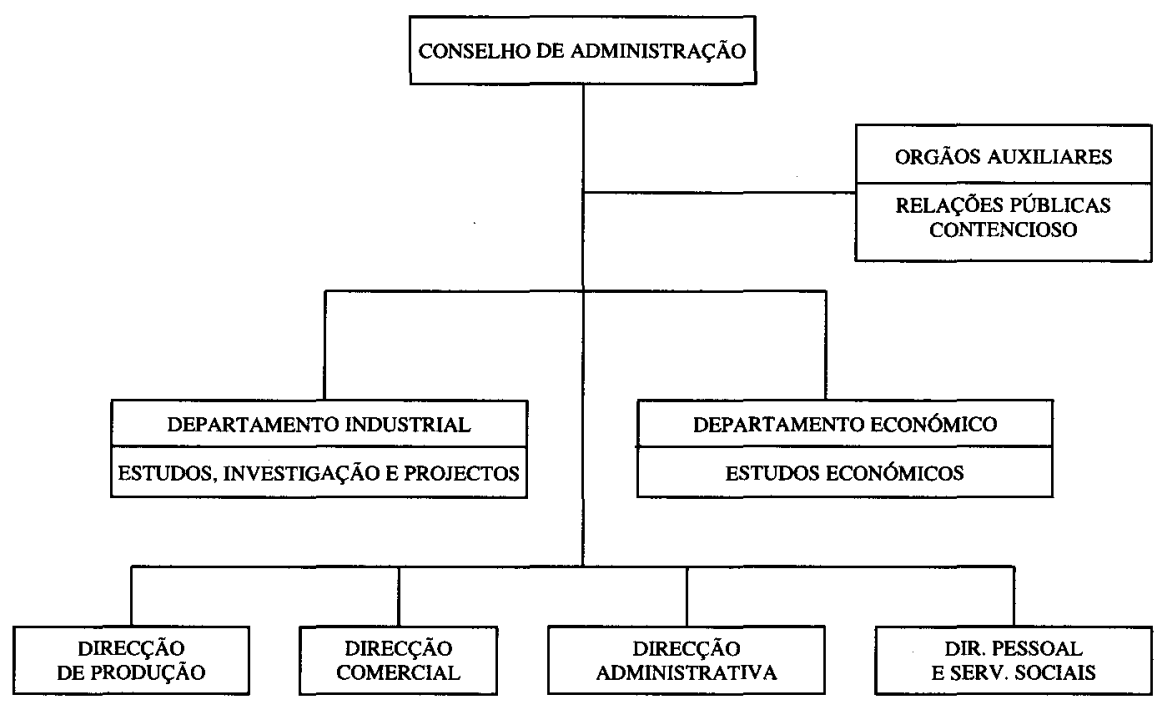

Fonte: Arquivo da Metalurgia Casal (AMC), Ordem de Serviço n. ${ }^{\circ} 12,1970.07 .13$.

A Direcção de Produção procede às alterações necessárias, a fim de assegurar «uma produção mensal de 5000 motores a partir de Janeiro de $1971 »^{76}$.

Ainda em 1970, na sequência de iniciativas anteriores, é dada uma importância superlativa à publicidade, à promoção da marca e da empresa; surgiu, também, um periódico mensal de empresa - o Motonotícia Casal -, onde eram divulgados os pontos de vista da direcção. Foi também, neste ano, que tiveram início os cursos para quadros médios e as reuniões de análise da produtividade.

Nesse ano, o volume de vendas continuou a registar acréscimos significativos (34\% em relação a 1969). Apesar do crescente alargamento de mercados, dos 95000 contos de vendas, só 10000 contos correspondem a vendas no mercado externo.

Tempo de arrumar a casa, em 1970 não há lançamento de produtos novos. No entanto, foram realizados estudos para o fabrico de uma motocicleta e de um novo ciclomotor e iniciou-se a renovação dos modelos de concepção considerada ultra- 
passada. Pensado desde 1969 , foi também nesse ano que nasceu o projecto de construção uma fábrica de automóveis. O pedido daria entrada na Direç̧ão-Geral dos Serviços Industriais em 1971.01.15 e seria deferido em 29 de Setembro.

Como explicação das dificuldades sentidas ao longo do ano de 1971, a empresa evoca «factores de variada índole que determinaram forte tendência inflacionista, a par de uma relativa estagnação na expansão económica» ${ }^{77}$. Mesmo assim, a Metalurgia Casal registou um acréscimo de $35 \%$ no volume de negócios. Por esse acréscimo foram responsáveis o mercado ultramarino e o mercado externo; 55\% dos veículos produzidos destinavam-se a esses mercados. As exportações representaram um acréscimo de $100 \%$ em relação ao ano anterior ${ }^{78}$. Esses resultados ficaram a dever-se a «uma intensa acção dinamizadora dos factores de venda no mercado. Alguns modelos foram retirados da comercialização por não corresponderem às exigências do público e outros foram lançados» ${ }^{79}$.

No entanto, dado o desmedido aumento de encargos, o resultado do exercício é assaz modesto. São gastos cerca de 10000 contos no apetrechamento tecnológico, em alguns sectores, e são iniciados os desenhos de novas instalações ${ }^{80}$.

No ano de 1972 continuavam a registar-se os sinais recessivos antes referidos. «O sector do ciclismo motorizado não viu aumentada a capacidade de absorção do mercado, apesar do aparecimento de novos modelos e da melhoria de qualidade dos produtos oferecidos» ${ }^{81}$. Nessas circunstâncias, «a taxa de expansão, expressa em volume de negócios, foi inferior a $5 \%$ \%. Entre as causas imediatas para justificar tal situação, a empresa considera as seguintes:

1. Elevação dos preços (agravamentos salariais - pela entrada em vigor do Contrato Colectivo de Trabalho dos Operários Metalomecânicos - e agravamento dos preços das matérias-primas).

2. Sobreprodução (proliferação desordenada de pequenos montadores com baixa qualidade e com reduzidíssimos gastos de estrutura, vendendo a preços reduzidos).

3. Aumento significativo da concorrência de produtos similares de origem estrangeira, especialmente no campo dos motores, sem que tenha havido qualquer entrave oficial à sua entrada.

4. E, finalmente, a obrigatoriedade do uso do capacete ${ }^{82}$.

A empresa procura reforçar as suas posições no sector. As participações em empresas como a Sotam (Mourisca do Vouga) e a Fundador (Sangalhos) terão de ser compreendidas desse modo. Mas as suas atenções não estavam voltadas apenas para o magro mercado interno.

A procura de penetração em mercados evoluídos é feita à custa de inúmeras 120 campanhas, «de uma tenaz política de promoção e prospecção de mercados». Em 
contrapartida, diminuíram as exportações para as colónias, devido ao sistema de contingentação que passou a vigorar durante esse ano.

Em estreita consonância com a política do novo pacto colonial (1961-71), dirigida no sentido da industrialização de Angola, a Metalurgia Casal decide investir naquela colónia. A conjuntura era favorável. «É na década de 60 que tem início um período de arranque industrial na principal colónia portuguesa, acompanhado por capital financeiro» ${ }^{83}$. Na reunião do seu Conselho de Administração, de 1972.03.10, foi deliberado conceder procuração a João Gonçalves Casal, filho do empresário João Francisco do Casal, para, em nome da empresa, «tratar de todos os actos necessários, inclusivamente a outorga da escritura respectiva, à constituição de uma sociedade» ${ }^{84}$. Um mês depois, o conselho de administração reúne novamente por causa da sociedade por quotas constituída em Angola, com sede nas proximidades, a norte de Luanda ${ }^{85}$.

\section{QUADRO III}

METALURGIA CASAL (ANGOLA), L. ${ }^{\text {DA }}$

Duração: por tempo indeterminado

Sede: Viana, Luanda.
1972.03.25

Capital social $3000000 \$ 00^{1}$

\begin{tabular}{|c|c|c|c|c|}
\hline Sócios & Profissões & Funções & Quotas & $\%$ \\
\hline Metalurgia Casal, SARL & & Gerente & $1650000 \$ 00$ & 55 \\
\hline Artur Simões Santiago $^{2}$ & Comerciante & & $300000 \$ 00$ & 10 \\
\hline Centro Ciclista do Lobito, L. ${ }^{\text {da }} 3$ & Comerciante & & $750000 \$ 00$ & 25 \\
\hline Francisco Marques Ferreira ${ }^{4}$ & Comerciante & & $300000 \$ 00$ & 10 \\
\hline
\end{tabular}

Fonte: AMC, Acta n. ${ }^{\circ}$ 15, Livro de Actas do Conselho de Administração, fl. $9 \mathrm{v}$,

1. Capital realizado em dinheiro. 2. Residente na cidade do Lobito. 3. Representado pelo sócio gerente, Artur Simões Santiago. 4. Residente na cidade de Luanda.

Mais tarde, já depois de Abril de 1974, seria realizado um aumento de capital e alterado (parcialmente) o pacto social da Metalurgia Casal (Angola), L. da Dos $3000000 \$ 00$ iniciais, passar-se-ia para $6000000 \$ 00$, conforme decisão tomada em Conselho de Administração ${ }^{86}$. De acordo com o texto da escritura realizada em Luanda, a importância desse aumento de capital seria «efectuada pela subscrição de quatro novas quotas, na proporção das já existentes ${ }^{87}$. Logo que a nova unidade estivesse a produzir motorizadas, a Metalurgia Casal (Angola), L. ${ }^{\text {da }}$ tencionava alargar a gama de produtos, pensava «instalar a fundição injectada de alumínio, para fechaduras, portas, cubos de motorizadas, caixas de motores, etc.». 
Apesar das dificuldades da conjuntura, a Metalurgia Casal, SARL conhece, em 1972, um período de dinamismo. Evocando a grande «expansão dos negócios da empresa, da fabricação, em série, dos motociclos de $125 \mathrm{~cm}^{3}$, dos estudos e projectos de novos veículos, nomeadamente dos motociclos de $350 \mathrm{~cm}^{3}$, e $500 \mathrm{~cm}^{3}$, dos preparativos para se instalar uma unidade fabril, em Angola, e dos estudos técnico-económico-financeiros para a instalação de uma Empresa de fabricação de veículos automóveis», João Casal propôs, em reunião do Conselho de Administração, de 1973.03.26, o aumento de capital da Metalurgia Casal, SARL para $60000000 \$ 00$. Essa alteração seria feita pela emissão de vinte mil acções com o valor nominal de mil escudos cada uma. Depois de discutidas as condições, ficou assim a redacção das mesmas: «a) cinco mil acções por incorporação de reservas. Os actuais accionistas terão direito a receber uma acção por cada oito que possuírem, mediante o pagamento do imposto de mais-valia; $b$ ) cinco mil acções com reserva de preferência para os actuais accionistas ao preço de mil escudos, cada uma, na proporção das que possuírem (artigo quinto parágrafo único). Todas as acções sobrantes serão atribuídas, sujeitas a rateio, aos accionistas que no acto da subscrição declararem desejá-las, ao preço acima referido; $c$ ) dez mil acções para o público em geral, sujeitas a rateio, e ao preço de mil e quinhentos escudos cada uma; $d$ ) a liberação das novas acções, a realizar em numerário, efectuar-se-á no acto da subscrição» ${ }^{88}$.

Alguns meses depois, por escritura de 1973.12.28, é realizado o reforço de capital, em $20000000 \$ 00$, e alterado parcialmente o seu Pacto ou Estatutos Sociais (números 1 e 2 do art. $4 .^{\circ}$ ). Neste aumento de capital, por reserva de preferência e por incorporação de reservas, foram subscritas dez mil acções (cinco mil em cada uma das modalidades, respectivamente), por sessenta e seis subscritores. De entre eles, destacam-se, pelo número de acções subscritas, João Francisco do Casal (2 500), João Gonçalves Casal (503), Manuel Francisco do Casal (500), José de Matos Lima (332), Marcelino dos Santos \& C. ${ }^{a},{ }^{\text {La }}{ }^{\text {da }}$ (300), Amândio Pereira Simões (187), Casal \& Irmãos, L. ${ }^{\text {da }}$ (125); depois há um grupo de subscritores com 25-40 acções. Os restantes ficam abaixo desse número. É evidente, pois, um reforço da posição dos administradores da Metalurgia Casal, do Grupo Casal e do seu presidente.

Na subscrição destinada ao público, a totalidade das acções foi subscrita pelas seguintes entidades bancárias: Banco Espírito Santo \& Comercial de Lisboa (1590), Banco Borges \& Irmão (1584), Banco Português do Atlântico (1323), Banco Nacional Ultramarino (1239), Banco Totta e Açores (1147), Banco Pinto \& Sotto Mayor (1069), Banco Pinto de Magalhães (1034), Banco Fonsecas \& Burnay (680) e Banco do Alentejo (330).

Algumas propostas (aprovadas) de alteração dos estatutos, dando mais poder de decisão ao Conselho de Administração, foram introduzidas neste período.

Em Moçambique, colónia mais afastada geográfica e economicamente, a estratégia da Casal foi diferente da adoptada em Angola. Por razões que se prendem 
imediatamente com a reduzida dimensão do mercado de motorizadas e com a significativa penetração das marcas japonesas, a Metalurgia Casal opta, na grande colónia do Índico, por uma outra modalidade. Tendo já dois postos de venda - um em Nampula e outro em Lourenço Marques -, a empresa de Aveiro celebra, em Setembro de 1973, um contrato com a Fábrica de Bicicletas de Moçambique, SARL, com sede na Parcela, nos arredores de Lourenço Marques. Esta empresa ficava com a comercialização exclusiva dos veículos Casal, em todo o território moçambicano, por um período de três anos. Esse acordo previa a possibilidade da empresa moçambicana «instalar uma linha de montagem dos veículos da marca Casal» ${ }^{89}$. Os motores seriam fornecidos já montados e a montagem dos veículos deveria seguir as instruções dos serviços técnicos da Casal. Por esse contrato, a empresa moçambicana ficava sujeita, também, à inspecção da empresa representada, que apreciaria os elementos de produção, de gestão e condições técnicas de fabrico da linha de montagem, através da visita periódica de seus representantes qualificados. Ainda se comprometia a Fábrica de Bicicletas de Moçambique, SARL a pagar à Metalurgia Casal um "royalitie" de $1 \%$ do valor CIF de cada veículo montado, a partir do momento em que a sua integração de componentes ultrapassasse a fase de pintura, cromagem e aplicação de aros e raios em cada veículo. Para dirimir quaisquer conflitos, a empresa aveirense pedia o recurso à arbitragem, que se realizaria em Aveiro, e, se houvesse necessidade de recurso às vias judiciais, o tribunal competente seria o desta cidade».

Ao referido contrato foi acrescentado um anexo, contendo os preços que vigorariam em 1973, bem como as condições de aumento dos preços nos anos seguintes da sua vigência, ainda que pudessem ser levadas em consideração as condições de mercado, «mas de molde a que os aumentos de preços não ultrapassassem as percentagens então verificada na Metrópole».

\section{MERCADOS, PRODUTOS E SUA PROMOÇÃO}

A adesão à EFTA, em 1960, ficaria «a constituir, simbolicamente, o fim da autarcia e o início do processo de abertura que viria a ser longo e contraditório, mas inexorável. No fundo, significou a vitória da ideia de que a estratégia de desenvolvimento já não podia passar só, nem sobretudo, pelo mercado interno metropolitano: a política de substituição de importações, um tanto à revelia do próprio [II] Plano, vai dando lugar a procedimentos que dão primazia à exportação» ${ }^{90}$.

Em 1972, o jornal da empresa testemunhava a continuidade da orientação inicial: «continuamos a fabricar acima de tudo motores, sendo as máquinas apenas para exportação»" ${ }^{91}$. De facto, a Metalurgia Casal, SARL «nasceu quase cem por cento para substituir as importações [...]. O mercado interno era essencialmente 
consumidor de motores - porque não queríamos fazer concorrência aqui enquanto o mercado estrangeiro e colonial era consumidor de motorizadas ${ }^{92}$. Foi a política de substituição de importações que levou João Casal a privilegiar, antes de mais, o fabrico de motores. Até a opção pela construção da "scooter" (concebida para ser equipada com motor Zündapp) poderá ser assim explicada; é que, não fazendo concorrência aos fabricantes de motorizadas (que lhe compravam os motores), com a Carina S 170, a Metalurgia Casal assegurava, para si, um espaço ocupado apenas por marcas estrangeiras.

\section{QUADRO IV}

VENDAS DE MOTORES E MOTORIZADAS, 1967-1969

\begin{tabular}{|l|r|r|r|r|r|r|}
\multicolumn{1}{c|}{} & \multicolumn{2}{|c|}{1967} & \multicolumn{2}{c|}{1968} & \multicolumn{2}{c|}{1969} \\
\hline \multirow{2}{*}{ Produtos } & Contos & $\%$ & Contos & $\%$ & Contos & $\%$ \\
\hline \multirow{2}{*}{ Motores } & 37761 & 59,6 & 51040 & 75,3 & 58414 & 78,0 \\
Motorizadas & $25541 *$ & 40,4 & 16716 & 24,7 & 16500 & 22,0 \\
\cline { 2 - 7 } Totais & 63305 & 100,0 & 67756 & 100,0 & 74914 & 100,0 \\
\hline
\end{tabular}

Fonte: AMC, Inquérito à indústria de fabrico de motores térmicos, Março de 1970.

* Vendas da Carina S 170: 25509 120\$00; vendas da Casal K 160: 32 000\$00.

Motores referenciados em 1967: M148, M151, M152 e M153; em 1968: M131, M149 e os anteriores; em 1969: todos os anteriores e M134, M136, M142 e M143.

Em 1945, Corradino D’Ascanio criara a Vespa, um dos maiores sucessos comerciais da indústria motociclística que invadiu, desde então, todos os mercados. Ao optar pelo fabrico de uma "scooter", a Metalurgia Casal explorava um segmento dominado pela Vespa, pela Lambretta, das fábricas Piagio e Innocenti, pela Goggo e outras, embora a oferta de "scooters" de baixa cilindrada fosse escassa $^{93}$. Mas, mesmo assim, nunca foi posta de parte a hipótese de produzir motorizadas; e alguns modelos - como a Casal K 181 — viriam a constituir um sucesso comercial assinalável. Também a produção de motores para utilização variada na agricultura (o motor M136, por exemplo, tinha um uso alargado, que ia das motobombas, moto-pulverizadores-atomizadores, motogeradores, sem-fins de elevação de cereais, ventiladores-limpadores de cereais) está, de algum modo, relacionada com as peias do Condicionamento Industrial. 


\section{QUADRO V}

VENDAS NOS MERCADOS INTERNO (MI), COLONIAL (MC)

E ESTRANGEIRO (ME), 1971-1973

\begin{tabular}{|l|r|r|r|r|r|r|r|r|r|}
\hline & \multicolumn{3}{|c|}{1971} & \multicolumn{3}{c|}{1972} & \multicolumn{3}{|c|}{1973} \\
\hline \multirow{2}{*}{ Produtos } & MI & MC & ME & MI & MC & ME & MI & MC & ME \\
\cline { 2 - 9 } N de motores $^{\text {o de veículos }}$ & 29000 & 305 & 134 & 29704 & 134 & 107 & 11582 & 432 & 0 \\
$\mathbf{N}^{\circ}$ & 2542 & 1512 & 1826 & 4533 & 614 & 2018 & 3128 & 16 & 1666 \\
\hline
\end{tabular}

Fonte: AMC, Total de Vendas, 1971-1973. A Grécia era o destinos dos motores exportados.

FACTURAÇÃO TOTAL, 1967-1973

\begin{tabular}{|c|c|c|c|c|c|c|c|}
\hline ANOS & $\mathbf{6 7}$ & $\mathbf{6 8}$ & $\mathbf{6 9}$ & $\mathbf{7 0}$ & $\mathbf{7 1}$ & $\mathbf{7 2}$ & $\mathbf{7 3}$ \\
\hline Totais & 63305 & 67756 & 73164 & 94270 & 122670 & 129770 & 165000 \\
\hline
\end{tabular}

Fonte: AMC, Total de Vendas, 1969-1973.

Até ao início dos anos 70, os produtores japoneses ainda não haviam penetrado no mercado de motos e motorizadas. As marcas mais decisivas eram as alemãs e italianas; de entre elas, destacam-se a Zündapp, a Sachs-S.I.S., a Flandria, a Hercules, a Puch, a BMW, a KTM, a Lambretta, a Parilla, a M.M, a Goggo, etc. $\mathrm{E}$ havia ainda marcas inglesas como a B.S.A. Em muitos casos, os motores eram montados por um escasso número de unidades ${ }^{94}$. Os «motores para bicicletas» eram fabricados (de forma quase artesanal) pelas empresas António Peixoto, L. ${ }^{\text {da }}$ e Motores Alma, L. ${ }^{\text {da } 95}$.

Após a conclusão do primeiro motor, no fim de Maio de 1966, a sua produção industrial tem início perto de um mês depois. Desde então, o crescimento foi muito rápido. Nos restantes dias desse mês de Junho, a empresa produzia mais 121 unidades. A partir de então, o ritmo da saída de novos produtos testemunha a natureza do empreendimento:

1966.06.21 — Início da produção industrial do primeiro motor Casal.

1966.10.26 — Início da produção do primeiro motor concebido para uma "scooter" própria.

1966.11.18 - Início da produção da "scooter" da Casal, a Carina S 170.

1966.12.31 - A empresa conclui um total de 8770 motores e 350 scooters".

1967.09.15 - Conclusão do primeiro motor de 50 c.c., com duas velocidades manuais (M148). 
Quando se preparava o início da produção do primeiro motor «genuinamente português» (e, meses depois, com o começo da produção da Carina), a empresa convoca a imprensa, organiza visitas, anuncia os seus produtos ainda em projecto, torna conhecidas as suas instalações (escola de aprendizes, laboratórios, ferramentaria, sala de desenho, sala de experiências, cantina, armazéns, etc.) e divulga os seus projectos imediatos e futuros.

A inclusão de figuras de topo do Estado e da Igreja acabava por fazer dessas visitas um 'acontecimento', com generosa cobertura nos jornais. Na visita «pré-inaugural», no final de Maio de 1966, o P. e Manuel Caetano Fidalgo, director do Correio do Vouga, «presidiu ao baptismo do primeiro motor Casal» e os jornais deram destaque ao evento ${ }^{96}$. A imprensa regional, especialmente esta, tem, da empresa, uma imagem deveras encomiástica.

O Lutador fornece testemunhos importantes desse esforço inicial de construção e promoção da marca Casal: «numa demorada e interessante visita pela vastidão das suas instalações, os visitantes recebiam explicações dos administradores e técnicos da Empresa, enquanto percorriam a Fábrica entre imensas filas de máquinas [...]. Para a maioria dos visitantes, a grandiosidade das instalações fabris era uma surpresa muito agradável, posto que a ninguém passava pela cabeça que Portugal já contasse com uma Fábrica do género tão moderna e eficiente» ${ }^{97}$. Também o Litoral dá um bom testemunho dessa política: «é já sobejamente conhecida a actividade da Empresa, mas muitos ignoram que esta fábrica constitui, no seu género, um dos mais modernos estabelecimentos produtores da Europa» ${ }^{98}$. Acrescentava o jor-

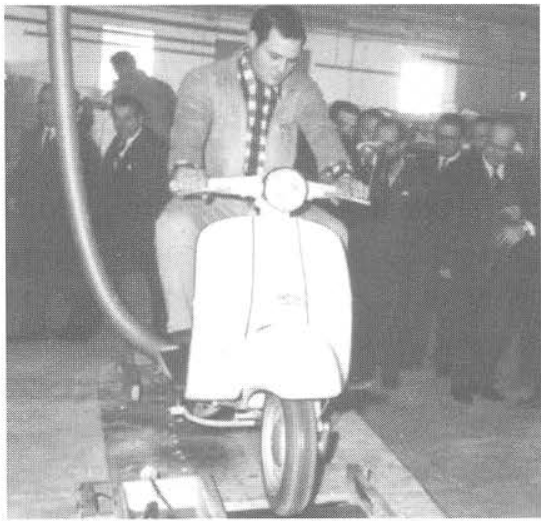

Fig. 2 - Teste da Carina na visita do ministro Ferreira do Amaral, 1966 (APJFC) nal: «como reflexo da sua ascendência, as actividades desta empresa estão a despertar as atenções e invulgar interesse entre os especialistas em particular, e os industriais em geral. As visitas sucedem-se. De estudo umas, de trabalho outras. Professores e estudantes de engenharia e de escola técnicas; operários e todos os que se interessam por estes problemas, ascendem a muitas centenas os que ali se têm deslocado a fim de verificar o funcionamento da maquinaria e a produção do que é o primeiro veículo motorizado inteiramente fabricado em Portugal» ${ }^{99}$. O Eng. Ferreira Dias Júnior visitaria, com os seus alunos do Instituto Superior Técnico, as instalações da empresa por diversas vezes, desde 1965. No início da produção da Carina S 170, Ferreira Dias esteve presente, na qualidade de Director Geral dos Serviços Industriais ${ }^{100}$. 
A direcção da Empresa promovia as visitas à fábrica, também, «com o intuito de preparar mais acertadamente os seus agentes para uma venda em alta escala, mentalizando-os ao mesmo tempo contra a tradição tão arreigada entre nós, de que o que é português não presta». A última visita, que o Litoral refere, reuniu «cerca de sessenta distribuidores e agentes de vendas das províncias do Algarve e do Alentejo», com a cobertura da imprensa da região.

Mas o "marketing" não se restringia às visitas. Desde início que a Metalurgia Casal investe em publicidade, ainda que datem apenas de 1968 as primeiras despesas discriminadas com anúncios na rádio, televisão e jornais: «Não estamos sós no mercado, temos concorrência. É necessária uma forte acção publicitária e de toda uma série de meios» ${ }^{101}$. Nesse ano de 1968 , as despesas com a promoção dos produtos «atingiram Esc. $705702 \$ 40$, ou seja, cerca de $40000 \$ 00$ mensais $^{102}$. Em 1969 foram gastos $1800000 \$ 00$ com publicidade dos produtos na rádio, imprensa, TV, feiras, e outros ${ }^{103}$. Em 1971, havia publicidade radiofónica incluída em programas desportivos e publicações da especialidade ${ }^{104}$. Desde início, a essa publicidade juntava-se a que era custeada por construtores de motorizadas, como a E.F.S., que anunciavam os seus veículos equipados com motores Casal ${ }^{105}$.

As corridas de motos e motorizadas eram, também, meios eficazes de divulgação das marcas. A Casal soube tirar partido desse recurso criando, em 1967, o Grande Prémio Casal, embora só em 1969 se possa dizer que têm início as corridas promovidas pela empresa ${ }^{106}$. Em Junho de 1971 é inaugurada uma pista de "motocross". Nessa altura, o jornalista francês de desporto, Henri Berchet, considerava que «um acontecimento destes não é vulgar, mesmo em países onde o motociclismo de competição possui fundas raízes e goza de grande popularidade» ${ }^{107}$.

Todos esses aspectos, aliados às provas dadas pelo "know-how" alemão (os primeiros motores estavam muito próximos dos motores Zündapp), permitiram que os produtos Casal gozassem de muito boa reputação e não thes foi difícil conquistar mercados, durante o período analisado. Entre os aspectos mais salientados pelas publicações da especialidade, importa referir a potência dos motores e o bom comportamento dos veículos. O melhor testemunho disso reside no sucesso dos produtos Casal em mercados exigentes como os da Dinamarca, Holanda, Alemanha e Suécia. Não sendo descurados, os aspectos estéticos não constituíam, então, a maior preocupação das empresas, pois, os mercados eram mais sensíveis a outras qualidades como a robustez, a resistência e a fiabilidade dos produtos.

Em finais de 1974, a revista Motor transcrevia uma apreciação crítica de técnicos franceses à motorizada Casal $\mathrm{K} 187 \mathrm{~S}$ (que a empresa fotocopiou e enviou aos seus representantes). Desse teste, fica a ideia de que aquela motorizada de 50 c.c. era apreciada pela sua robustez e conforto, «comparável ao de uma máquina de 125 c.c.» ${ }^{108}$. Entre as vantagens, são referidas: a «seriedade de realização, conforto e suspensão, robustez e velocidade de ponta elevada, equipamento 
completo, autonomia do reservatório e pedaleira muito bem concebida». Os aspectos que mais deixavam a desejar eram a «falta de "souplesse" do motor, ruído intenso a partir das $7000 \mathrm{rpm}$, caixa imprecisa e comando de embraiagem duro».

Desde o início dos anos 70, a empresa adopta um esquema de testes que visa pôr motores e componentes dos seus veículos à prova, em condições extremas de utilização. Os relatórios apresentados permitiam a realização de ajustamentos e modificações várias. Para o lançamento da Casal K 270, de 125 c.c., em 1973, «foram feitos $15500 \mathrm{Km}$, em 48 dias, em percurso de estrada e cidade, sendo atravessados os seguintes países: Portugal, Espanha, França, Itália, Jugoslávia, Bulgária, Turquia, Grécia, Áustria, Alemanha, Suíça, Dinamarca, Suécia, Holanda e Bélgica» ${ }^{109}$.

Na Feira de Março de 1970 é exposta a K 260, «a primeira motocicleta nacional» $(125 \text { c.c., } 12 \mathrm{cv} \text {. })^{110}$, que só seria colocada no mercado em 1972. Foi com grande regozijo que a empresa anunciou o início da comercialização da «moto cem por cento portuguesa»: «Com o lançamento em produção normal da K 260 a nossa empresa transformou-se na primeira fábrica nacional a produzir inteiramente uma motocicleta. $O$ projecto tinha já a idade da fábrica [...]. A nossa primeira motocicleta é uma máquina robusta de aparência e de construção, ensaiada já durante muitas centenas de milhares de quilómetros, durante os quais inúmeros pormenores foram revistos e analisados». O público alvo é a «maioria da população trabalhadora [que] não se impressiona com bonitinhos ineficazes que mais não são do que fontes de avarias e aborrecimentos» ${ }^{111}$. Entre as vantagens são notadas «a robustez, a duração, a libertação dos limites de velocidade e, a maior de todas, a possibilidade de transportar duas pessoas. $O$ casal trabalhador, o pai que no caminho deixa o filho na escola apreciarão muito esta economia de transportes [...]. Ir para o emprego nas grandes cidades ou sair delas ao fim de semana numa motocicleta faz parte da vida comum do comum cidadão francês, inglês ou alemão» ${ }^{112}$.

A penetração nos mercados externos era realizada na sequência de contactos nas feiras do sector. As feiras mais importantes eram (e continuam a ser) as de Milão e de Colónia, que se realizam de dois em dois anos, alternadamente.

As comitivas que se deslocavam às mostras internacionais eram compostas por dois sectores: o comercial e o técnico. Nas feiras estavam presentes potenciais clientes do mundo inteiro. Fazia-se uma mostragem dos produtos e tentava-se interessar possíveis clientes. Por outro lado, procurava fazer-se uma pesquisa do que estava a ser produzido pela concorrência, bem como se tentava averiguar como funcionavam os mercados de acessórios, componentes, etc.

Em 1969, a empresa fazia-se representar na Feira de Milão. O "stand" da Casal ainda não corresponderia - em situação e dimensão - às responsabilidades começadas a criar internacionalmente ${ }^{113}$. Ali foram expostos os motores M 148, M 149, M 152 e M 131, a "scooter" Casal S 170 e as motorizadas K 181 e K 163, além de 
um motor M 151, «alterado para competição por uma firma holandesa, motor que despertou muita curiosidade entre os visitantes $\gg^{14}$. Para o público do certame, segundo a opinião da delegação da Casal, o mais importante eram «a potência dos motores, o número de velocidades e a sua cilindrada [...]. A nossa $\mathrm{K} 181$, dado que é uma máquina com aspecto de moto, equipada com motor de apenas $50 \mathrm{~cm}^{3}$, deu bastante nas vistas e gerou-se um movimento de muito interesse e ainda maior ao ter-se conhecimento que a sua carroçaria era feita em metal leve injectado em vez de chapa estampada como a grande maioria das máquinas expostas» ${ }^{115}$.

Em 1970, a Metalurgia Casal participou nas mostras de Gotemburgo e na de Colónia, «onde foram estabelecidos muitos contactos interessantes» ${ }^{116}$. Desde aí, a empresa estaria presente nos mais importantes certames do sector. Todas as representações em países como a Grécia e a Pérsia foram conseguidas em feiras do mundo motorizado.

Entre os países do mercado externo, detinham um lugar de relevo a Holanda, a Dinamarca e a Grécia. Em 1973 contava já com representantes nos países referidos e nos EUA ${ }^{117}$.

Comparado com o mercado europeu, o mercado colonial era pouco significativo, apesar dos investimentos realizados em Angola e das considerações do director de vendas que, em 1972 , ainda o via como «um vasto mercado a explorar» ${ }^{18}$. A orientação política traduzia-se nas dificuldades que «impediam os agentes importadores de obterem licenças de importação e outras necessárias à permissão da entrada de veículos nas colónias ${ }^{119}$.

Mas o projecto que mobilizou a empresa e a opinião pública foi o da construção do automóvel Casal. Pela lacónica autorização ministerial, com data de 1971.09.01, a Metalurgia Casal, SARL ficava «autorizada, nos termos da alínea a) do art. $1 .^{\circ}$. do Decreto-Lei $n .^{\circ} 46.666$, de 1965.11 .24 , a construir automóveis ligeiros de passageiros, sob as seguintes condições:

a) Todos os veículos obedecerem à designação de "Produto de Fabrico Nacional", nos termos do Decreto n. ${ }^{\circ} 37.683$, de 1949.12.24;

b) Todos os veículos serem equipados com motores que obedeçam à designação de "Produto de Fabricação Nacional", nos termos do Decreto n. ${ }^{\circ} 37.683$, de 1949.12.24;

c) Esta autorização ser completamente independente do regime especial de montagem de veículos automóveis, estabelecido pelo Decreto-lei $\mathrm{n} .^{\circ}$ 44.104, de 1961.12.20.

Em 1969, no balanço do III Grande Prémio Casal, a direcção da empresa dizia aos jornalistas que, em 1972, esperava que os automóveis a integrar na prova fossem já de fabrico Casal ${ }^{120}$. De facto, a ideia de fazer uma fábrica de automóveis nasce, como se disse, ainda durante 1969. João Francisco do Casal entendia que 
o que o País precisava era de uma fábrica de automóveis e não de fábricas de montagem. No Natal de 1971, em entrevista ao jornal da empresa, o empresário não escondia o entusiasmo com o projecto que faria, de uma fábrica de motorizadas, uma fábrica de automóveis ${ }^{121}$.

Nesse projecto havia várias entidades interessadas. A Renault e a Schoussons - empresa de Lille que fabrica estruturas e carroçarias para a Renault — eram as principais. Técnicos das duas empresas estiveram em Aveiro para participar na elaboração dos estudos a apresentar à Secretaria de Estado da Indústria, e chegou-se à conclusão de que o carro que interessava construir seria muito próximo dos modelos Renault 15 e 17».

Esteve prevista, até, «a deslocação de alguns técnicos e desenhadores da Casal à empresa italiana de Pininfarina, que seria a responsável pela concepção do veículo». Por esse motivo, veio a Aveiro Renzo Carlo, genro do desenhador italiano. As discussões acerca das características e motorizações desse automóvel (1200 c.c., 1300 c.c. e 1600 c.c.) levaram um desenhador da empresa a interpretar 'tecnicamente' o projecto como mostra a imagem.

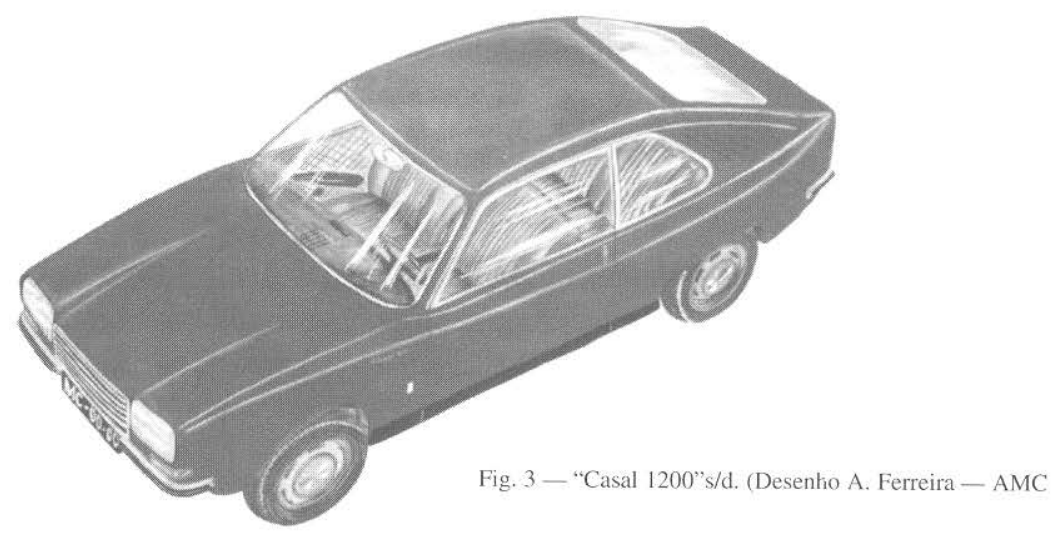

Mas os obstáculos à sua concretização surgem quase desde o início, apesar dc se ter conseguido o alvará. Foram elaborados estudos económicos, tecnológicos e financeiros indispensáveis. Dos estudos do projecto foram feitas várias cópias e enviadas à Secretaria de Estado da Indústria, sem que tivesse havido, depois, qualquer resposta ${ }^{122}$.

Ainda hoje é difícil aos dirigentes da empresa explicar as razões do insucesso do projecto, a partir do momento em que deu entrada na Secretaria de Estado da Indústria. Sem certezas, vagamente, são evocadas pressões de empresas que não veriam com agrado o aparecimento de um construtor apoiado pela Renault. Estariam nessa situação a Alfa Romeo, que intentava produzir o Alfa Sud, em Sines, a General Motors e a Ford. Em Setembro de 1963, a General Motors inau- 
gurara uma unidade de montagem de automóveis; alguns meses depois, em 1964, seria a vez da Ford iniciar a montagem de automóveis - dos modelos Anglia e Cortina -, na nova fábrica da Azambuja ${ }^{123}$.

Com a situação criada após 25 de Abril de 1974 não mais foi possível pensar numa fábrica de automóveis.

\section{TÉCNICOS E MÃO-DE-OBRA OPERARIA}

O Eng. Robert Erich Zipprich ocupa um lugar cimeiro na história da Metalurgia Casal, depois do seu fundador. Natural de Munique, este homem, «de extraordinária energia e invulgar formação técnica», fora director da BMW e da Zündapp-Werke GmbH. Desde 1965, procurou dotar a empresa a que se ligou, no fim da sua vida, «do que então havia de melhor em equipamento fabril, das técnicas de fabrico mais evoluídas, de tudo o que pudesse contribuir para que a nova unidade industrial desse os primeiros passos com segurança» ${ }^{124}$.

Já em Março de 1967, na primeira reunião da Assembleia Geral da Metalurgia Casal,

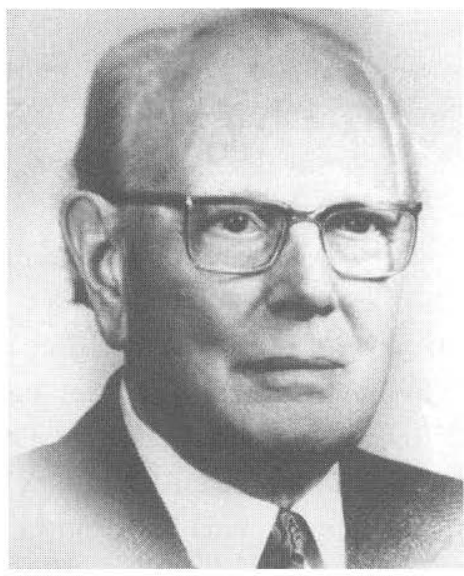

Fig. 4 - Robert E. Zipprich, s/d (AMC) SARL, Robert E. Zipprich fora alvo do apreço dos accionistas pela forma eficiente e excepcional como desempenhava as suas funções de Director Técnico, o que permitia «manter a empresa num nível ímpar no sector industrial a que se dedica». A memória da sua actividade, na empresa, ficou ligada, pois, à busca permanente da qualidade.

Durante o «período alemão» (1964 a 1970), é evidente a direcção e a influência técnica e organizativa da equipa germânica formada por técnicos de formação diversa, escolhidos e dirigidos por Robert Erich Zipprich. Foram, assim, contratados: Franz Xaver Hans Kulzer, engenheiro de máquinas; Rainer Pelikan, técnico de ferramentas; Rudolf Wörmann, mecânico e Friedrich Rudolf Bayer, técnico da Zündapp-Werke, além da intérprete, Gudrun Korth Pereira Ferraz. Em 1967, ainda seria contratado o técnico Johannes Manfred Rolf Tambrich, para a montagem de máquinas.

Para a solução dos inúmeros problemas de natureza técnica, Robert Erich Zipprich pôde contar, também, com a estreita colaboração de outros técnicos alemães que, a partir da República Federal da Alemanha, acompanhavam o decorrer dos trabalhos da construção dos primeiros motores. 
Entretanto, seduzidos por propostas mais tentadoras, os técnicos alemães foram saindo entre 1969 e 1970 . A reestruturação de 1970 iria permitir a ascensão de uma equipa maioritariamente composta por técnicos portugueses, formados durante os anos anteriores.

Nesse ano, o Eng. Robert Erich Zipprich adoece. Em Março desse ano, na sequência da reestruturação da empresa, ainda lhe é atribuída a coordenação do Departamento Industrial e da Direcção de Produção ${ }^{125}$. Mas a doença impôs a sua substituição, ainda que temporária. O lugar de Director Técnico seria (fugazmente) ocupado pelo Eng. Wolfgang Otto Pregitzer, que colaborava com a empresa, desde Janeiro de 1969, e havia sido nomeado adjunto da Administração para chefiar o Departamento Industrial (Estudos, Investigação e Projectos), no início de $1970^{1186}$. Este técnico - que posteriormente viria a auxiliar a empresa era responsável pela serralharia de Leixões e pelos produtos Estrela.

Em Maio de 1971, o Conselho de Administração reuniu sem Robert Zipprich, desde 1970.12.29 até 1971.05.28, data em que é apreciado o seu pedido de demissão ${ }^{127}$. É, então, nomeado para o substituir, como Director Técnico e como membro do Conselho de Administração, o engenheiro mecânico, João M. Senos Nunes da Fonseca, que fora admitido em Abril desse mesmo ano, e era, desde Março de 1970, Director de Produção ${ }^{128}$. Os restantes quadros superiores, ou foram recrutados no exterior, ou emergiram pelas suas qualidades e formação, ao longo dos primeiros anos de vida da empresa. A maioria saía da Sala de Desenho e da Ferramentaria, sectores-chave da fábrica.

Para iniciar a sua actividade, além da colaboração da equipa de técnicos, a empresa necessitava de trabalhadores com formação na área da metalurgia e metalomecânica. Houve, pois, alguma dificuldade em encontrar gente em número suficiente e com os requisitos exigidos. Durante os dois primeiros anos, a empresa manteve anúncios de pedido de serralheiros, torneiros, desenhadores, electricistas, empregados administrativos e outros trabalhadores especializados nas páginas dos jornais locais. Mas não estava só. Outras empresas metalúrgicas faziam pedidos insistentes da mesma natureza.

Apesar das dificuldades, a Metalurgia Casal soube atrair uma mão-de-obra já com níveis apreciáveis de formação, até aí ao serviço de empresas metalúrgicas e de pequenas oficinas artesanais. Além dos operários da J. Casal, foram recrutados trabalhadores com formação específica em empresas da região, como a Empresa

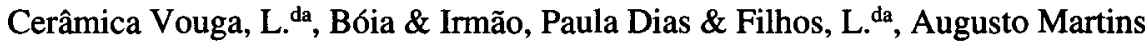
Pereira - ALBA, Estaleiros de S. Jacinto, Companhia Portuguesa de Celulose, Metalo-Mecânica e a Frapil, entre outras.

O quadro da distribuição geográfica dos trabalhadores recrutados dá conta de uma enorme dispersão, tendo como centro a cidade de Aveiro e a freguesia de Esgueira. 
QUADRO VI

PROVENIÊNCIA GEOGRÁFICA DA MÃO-DE-OBRA, 1964-74

\begin{tabular}{|l|r|r|r|r|r|r|r|r|r|r|r|r|}
\hline Localidades & \multicolumn{1}{c}{$\mathbf{6 4}$} & \multicolumn{6}{c}{$\mathbf{6 5}$} & \multicolumn{6}{c}{$\mathbf{6 6}$} & \multicolumn{6}{c}{$\mathbf{6 8}$} & \multicolumn{6}{c}{$\mathbf{7 0}$} & \multicolumn{7}{c}{$\mathbf{7 1}$} & $\mathbf{7 2}$ & $\mathbf{7 3}$ & $\mathbf{7 4}$ Total \\
\hline Esgueira & 15 & 36 & 94 & 53 & 47 & 48 & 96 & 22 & 8 & 16 & 3 & $\mathbf{4 4 0}$ \\
Aveiro & 18 & 52 & 74 & 33 & 29 & 27 & 46 & 29 & 5 & 3 & 2 & $\mathbf{3 2 7}$ \\
Cacia & & 9 & 42 & 12 & 22 & 28 & 70 & 24 & & 6 & & $\mathbf{2 1 4}$ \\
Albergaria & 2 & 5 & 37 & 14 & 15 & 24 & 35 & 13 & 4 & 7 & & $\mathbf{1 5 8}$ \\
Eixo & & 6 & 21 & 10 & 8 & 21 & 26 & 9 & 2 & 4 & 1 & $\mathbf{1 0 9}$ \\
Ílhavo & 1 & 8 & 18 & 12 & 10 & 5 & 26 & 8 & 2 & 2 & 3 & $\mathbf{9 9}$ \\
S. Bernardo & 4 & 14 & 17 & 6 & 6 & 4 & 19 & 7 & 2 & 4 & & $\mathbf{8 1}$ \\
Aradas & 7 & 16 & 20 & 6 & 6 & 5 & 8 & 5 & 2 & 2 & & $\mathbf{8 1}$ \\
Angeja & & 1 & 5 & 3 & 11 & 6 & 24 & 6 & 1 & & & $\mathbf{5 8}$ \\
S. João de Loure & & 2 & 3 & 3 & 15 & 7 & 12 & 7 & 3 & & & $\mathbf{5 6}$ \\
Estarreja & 1 & & 12 & 2 & 7 & 4 & 15 & 3 & 2 & 4 & 3 & $\mathbf{5 3}$ \\
Gafanha & 1 & 4 & 9 & 5 & 2 & 3 & 1 & 1 & 2 & & & $\mathbf{3 1}$ \\
Águeda & 1 & 12 & 2 & 2 & & 1 & & & & & $\mathbf{1 8}$ \\
Vagos & & & 3 & & & & 6 & 1 & & & 1 & $\mathbf{1 2}$ \\
\hline
\end{tabular}

Fonte: AMC, Fichas de Pessoal

Mas a dispersão é muito maior se procurarmos saber qual ou quais as empresas que fornecem maior número de trabalhadores, não nos permitindo dizer que a maioria, ou tão-só um grande número, veio desta ou daquela empresa. As pequenas oficinas artesanais forneceram, também, uma apreciável percentagem da mão-de-obra. Na região compreendida entre Albergaria, Águeda, Aveiro e Ílhavo havia cerca de 60 serralharias, cerca de uma vintena de fundições e pequenas unidades de fabrico de utensílios domésticos ${ }^{129}$.

Decisiva para a criação de uma empresa como a Metalurgia Casal foi a existência da Escola Industrial e Comercial de Aveiro. Como a Direcção da empresa verificava, os conhecimentos dos alunos permitiam-lhes a integração fácil numa empresa deste género. Aquele estabelecimento de ensino, fundado em 1893, viu aumentada a sua frequência desde a inauguração das novas e amplas instalações, em 1956. Em meados dos anos 60, mercê do fenómeno de urbanização e explosão urbana, as escolas do ensino secundário registam um número recorde de inscrições. No Liceu, no ano lectivo de 1966-67, matricularam-se 1514 alunos, mais 75 que no ano anterior. Na Escola Técnica, matricularam-se 2116 alunos, mais 110 que no ano lectivo de $1965-66$ e mais 1299 do que em $1955-56^{130}$.

Assim, os níveis de instrução dos trabalhadores da empresa são superiores à média registada pelo Inquérito Industrial de 1964. Naquele inquérito, entre a mão-de-obra ocupada na indústria, o pessoal com curso técnico e liceal, médio e 
superior computava-se em 3\%, enquanto na Metalurgia Casal, segundo as habilitações indicadas na admissão, esse número oscilou, no período estudado, entre 29,5 e $30,5 \%^{131}$. Note-se que muitos trabalhadores iniciaram os estudos ou continuaram a frequentar os cursos nocturnos da Escola Técnica de Aveiro.

\section{QUADRO VII}

HABILITAÇÕES DOS TRABALHADORES ADMITIDOS, 1964-1974

\begin{tabular}{|l|r|}
\hline Analfabeto & 62 \\
3. ${ }^{\text {c }}$ classe & 166 \\
4. ${ }^{\text {casse }}$ classe & 1000 \\
Ciclo Preparatório & 111 \\
Ensino secundário (técnico e liceal) & 391 \\
Curso médio e superior & 44 \\
Não discriminados & 31 \\
Sem indicação & 31 \\
\hline \multicolumn{1}{|c|}{ Total } & $\mathbf{1 8 0 5}$ \\
\hline
\end{tabular}

Fonte: AMC, Fichas de Pessoal.

A análise da evolução do número de trabalhadores, existentes em 31 de Dezembro de cada ano do período estudado, não permite obter uma imagem da natureza das dificuldades sentidas, como dos períodos de maior desenvolvimento. Mesmo assim, foi necessário recorrer a outras fontes para uma melhor compreensão dos fenómenos registados pelo movimento de entradas e saídas de trabalhadores. Atentemos nos gráficos e quadros seguintes:

\section{QUADRO VIII}

IDADES DOS TRABALHADORES ADMITIDOS, 1964-1974

\begin{tabular}{|c|c|c|c|c|c|c|c|c|c|c|c|c|}
\hline ANOS & 1964 & 65 & 66 & 67 & 68 & 69 & 1970 & 71 & 72 & 73 & 74 & Total \\
\hline $12-15$ & 9 & 23 & 33 & 25 & 20 & 32 & 52 & 21 & & 1 & & 2 \\
\hline $16-20$ & 9 & 52 & 89 & 36 & 34 & 26 & 99 & 20 & 4 & 6 & & 386 \\
\hline $21-25$ & 5 & 28 & 104 & 32 & 54 & 45 & 89 & 45 & 12 & 22 & 4 & 444 \\
\hline $26-30$ & 12 & 24 & 74 & 36 & 33 & 38 & 67 & 19 & 10 & 14 & 7 & 339 \\
\hline $31-35$ & 6 & 11 & 32 & 19 & 16 & 14 & 31 & 9 & 3 & 2 & 1 & 147 \\
\hline $36-40$ & 2 & 6 & 18 & 8 & 7 & 7 & 21 & 9 & 4 & 2 & 1 & 85 \\
\hline $41-45$ & 1 & 6 & 17 & 3 & 9 & 10 & 22 & 3 & & 3 & 1 & 76 \\
\hline $46-50$ & 2 & 2 & 5 & 2 & 3 & 7 & 12 & 7 & 2 & 3 & & 46 \\
\hline$>51$ & 3 & 4 & 6 & 2 & 9 & 8 & 12 & 6 & & 1 & & 51 \\
\hline Total & 49 & 157 & 379 & 164 & 185 & 187 & 406 & 140 & 35 & 54 & 14 & 1805 \\
\hline
\end{tabular}




\section{GRÁFICO 1}

EVOLUÇÃO DA MÃO-DE-OBRA, 1964-1974

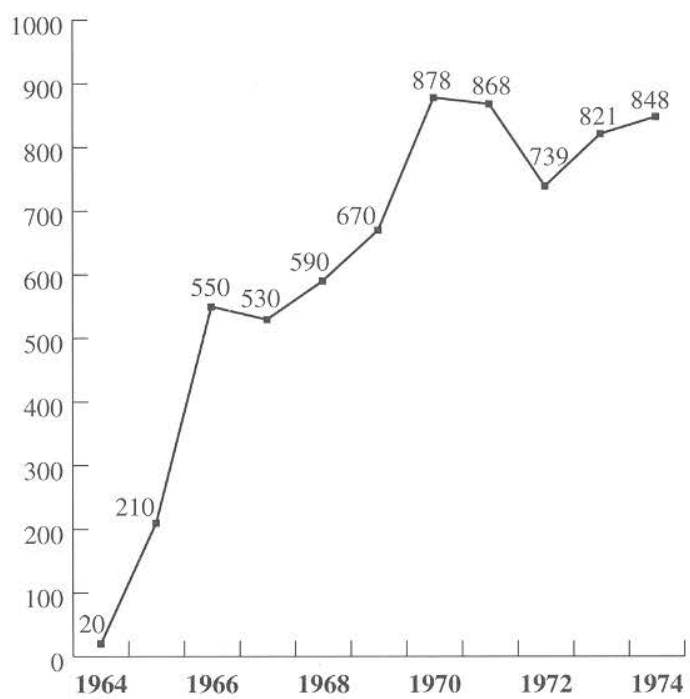

Fonte: Serviços de Pessoal

\section{GRÁFICO 2}

TRABALHADORES ADMITIDOS E DEMITIDOS, 1964-1974

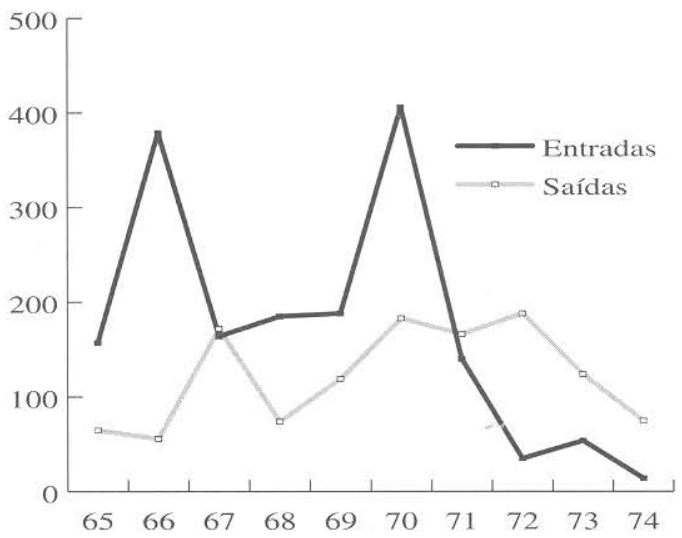

\begin{tabular}{|c|c|c|c|c|c|c|c|c|c|c|}
\hline ANOS & 65 & 66 & 67 & 68 & 69 & 70 & 71 & 72 & 73 & 74 \\
\hline ENTRADAS & 157 & 379 & 164 & 185 & 188 & 406 & 140 & 35 & 54 & 14 \\
\hline SAÍDAS & 65 & 56 & 172 & 74 & 119 & 183 & 166 & 188 & 124 & 75 \\
\hline
\end{tabular}


A explicação para a enorme saída de trabalhadores, especialmente durante os anos 67-68 e 70-73, parece estar ligada à vaga migratória, bem conhecida. São muitos os testemunhos dos destinos da maioria desses trabalhadores. Especialmente os que tinham vindo do campo ou de pequenas unidades cerâmicas manifestavam grandes dificuldades em se integrar na organização da empresa. As queixas de falta de assiduidade, ainda que não abrangessem todos os sectores da empresa, sentiam-se. $O$ número de despedimentos é insignificante, mas elevado é o número de abandonos do serviço, muitas vezes sem notificação alguma. Além da emigração, os destinos de muitos trabalhadores eram outras empresas que neste período, especialmente nos primeiros anos da década de 70 , começam a surgir ou a desenvolver-se por toda a região.

Os números referentes a 1967-68 têm, no entanto, outra explicação. Além da pressão da emigração, a Metalurgia Casal, ainda na fase de arranque, atravessou alguns meses de grandes dificuldades, provocadas pela concorrência de motores importados. Aos embaraços e aos elevados prejuízos, causados pela entrada de poeira no volante magnético e filtro da Carina S 170 - que obrigou a fábrica a interromper a produção e a um grande esforço com a reparação dos prejuízos causados aos compradores - , juntou-se a 'invasão' do mercado nacional com motores estrangeiros importados por empresas do ramo, nomeadamente pela Famel (Águeda) e pela Sachs-S.I.S. (Anadia). A concessão de licenças de importação de partes de motores acabava por facilitar a importação dos motores completos. Em face dessa situação, e depois de inúmeras exposições junto da Direcção Geral dos Serviços Industriais, como junto da Direcção Geral das Alfândegas, a empresa despede algumas dezenas de trabalhadores «para tentar pressionar o governo; à Metalurgia Casal tinha sido prometido apoio para se reduzirem as importações de produtos concorrentes. Importava-se indiscriminadamente. $\mathrm{Na}$ altura verificou-se que o que fora prometido não estava a ser cumprido e isso trazia-nos inúmeras dificuldades. A liberalização em curso conduzia à protecção de comerciantes e ao prejuízo da indústria que arrancara com a promessa de alguma protecção inicial. Apesar de tudo, as condições pouco se modificaram ${ }^{132}$.

$\mathrm{O}$ grosso dos trabalhadores que abandonaram a empresa tinha apenas a 4. ${ }^{2}$. classe; mesmo assim, a análise do quadro seguinte mostra a saída de um valor significativo de trabalhadores com o curso industrial (completo ou incompleto).

Outro processo que permitiu à Metalurgia Casal atrais um significativo volume de mão-de-obra qualificada foi a subida dos salários, o que levou alguns empresários da região a queixarem-se da «inflação dos salários» "133. As remunerações praticadas ficavam entre 5 e $25 \%$ acima dos valores das empresas donde vinham os trabalhadores admitidos. A excepção é constituída pelos salários das mulheres. Excluídas as (17) empregadas de escritório, a esmagadora maioria das 141 mulhe-

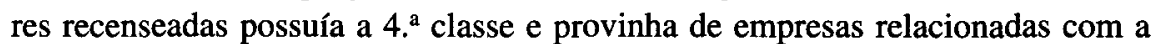
cerâmica e o sal. 
QUADRO IX

SAÍDA DE TRABALHADORES, 1965-1974

\begin{tabular}{|c|c|c|c|c|c|c|c|c|c|c|c|}
\hline ABILITAÇÕES & 65 & 66 & 67 & 68 & 69 & 70 & 71 & 72 & 73 & \multicolumn{2}{|c|}{74 Total } \\
\hline Analfabeto & & & 6 & 4 & 1 & 8 & 2 & 6 & 6 & 1 & 34 \\
\hline $3 .^{\mathrm{a}} \mathrm{e} 4 .^{\mathrm{a}}$ classe & & 36 & 111 & 46 & 83 & 123 & 108 & 114 & 81 & 60 & 762 \\
\hline Ciclo Preparatório & & 3 & 2 & 3 & 3 & 19 & 21 & 21 & 8 & 3 & 83 \\
\hline Curso de Liceu & 1 & 1 & 3 & 1 & 3 & & 2 & 7 & 4 & 1 & 23 \\
\hline Curso Comercial & & 2 & 9 & 4 & 4 & 7 & 5 & 6 & 3 & 4 & 44 \\
\hline Curso Industrial & 3 & 15 & 36 & 13 & 19 & 17 & 36 & 33 & 16 & 4 & 192 \\
\hline Curso Superior & & 3 & & 3 & 2 & 2 & 3 & 6 & 2 & & 21 \\
\hline Totais & 4 & 60 & 167 & 74 & 115 & 176 & 177 & 193 & 120 & 73 & 1159 \\
\hline
\end{tabular}

Fonte: AMC, Fichas de Pessoal. Dada a elevada variedade de situações, não se discrimina se as habilitações estavam ou não concluídas.

Os salários elevados, a dimensão das instalações, a juventude da maioria de quadros e operadores, bem como a impressiva imagem da empresa junto da opinião pública, poderão explicar a comunhão de interesses que se verificou, especialmente nos primeiros anos. Nessa altura construiu-se um ambiente de trabalho que levava muitos operários a passar na fábrica muitas horas depois do horário normal e mesmo aos sábados. A cidade não tinha meios para matar o tempo e a fábrica tornou-se um espaço de realização para muitos trabalhadores; desenvolveu-se um forte espírito de comunidade, em torno de uma ideia partilhada de que a fábrica também lhes pertencia ${ }^{134}$.

A partir de 1970, no âmbito da reestruturação já referida, a empresa promove um conjunto de acções de formação visando combater desperdícios, danos nas ferramentas, negligência passiva na execução de peças e falta de assiduidade. Numa das reuniões-colóquios, promovidas pela direcção da empresa e realizadas na cantina, António Vagueiro da Fonseca escrevia no jornal da fábrica que, além do significativo número de peças defeituosas, a falta de assiduidade era um problema que afectava a empresa no seu todo ${ }^{135}$. Com vista à optimização dos recursos existentes, através da participação dos trabalhadores, no âmbito da formação profissional extensiva a todo o pessoal, a empresa criou um Regulamento de Sugestões ${ }^{136}$.

\section{A ESCOLA DE APRENDIZES}

Com a criação de uma Escola de Aprendizes, a Metalurgia Casal assume uma posição pioneira na formação profissional no nosso país. 
Em 1956, João Francisco do Casal visitara a fábrica de tornos dos irmãos Traub, na Baviera. Ali pôde ver uma escola de aprendizes bem organizada e, em sua opinião, «foi aí que nasceu o sonho de vir a fazer uma escola de formação em Portugal». Depois dessa e da Zündapp, João Casal visitaria algumas outras empresas alemãs, com escolas de formação profissional.

Por essa razão, a escola de formação da Metalurgia Casal segue de muito perto o modelo alemão. As poucas (mas significativas) diferenças resultavam da efectiva ligação do ensino técnico oficial às empresas. Entre nós, essa relação, quando existiu, não era articulada, nem oficial. A Casal apenas podia apoiar e incentivar os aprendizes da sua escola a frequentar a Escola Industrial e Comercial de Aveiro, após o horário laboral.

A insistência do empresário, para quem a criação da escola de aprendizes se havia tornado «quase uma obsessão», bem como o reconhecimento da urgente necessidade de mão-de-obra com formação muito específica (especialmente no domínio da ferramentaria) acabaram por ditar o estabelecimento da escola de aprendizes, em 1965. Em Abril desse ano, João Casal contratou Abel G. Baptista, mestre das oficinas da Escola Industrial e Comercial de Aveiro. De acordo com as indicações que lhe foram dadas, este professor dá início a uma formação profissional bastante idêntica, no tocante a conteúdos programáticos, à que ministrava no estabelecimento de ensino oficial.

Cerca de um mês depois, o referido professor abandona a experiência e a empresa, indicando, para o substituir, o jovem mestre de oficinas da Escola Industrial e Comercial de Aveiro, José Teixeira da Rocha ${ }^{137}$. Este, então apenas com um vínculo contratual àquele estabelecimento de ensino, aceita o convite e dá continuidade ao trabalho encetado pelo primeiro. Dias depois, é contratado António Guardado de Almeida, até então contramestre da Escola Industrial e Comercial da Figueira da Foz ${ }^{138}$.

Para a direç̧ão da Escola, a empresa escolhe um alemão. Entre os elementos contratados por Robert Erich Zipprich contava-se Rainer Pelikan, que viera dirigir o sector-chave que era a ferramentaria. Pela sua formação, como pela sua experiência, foi escolhido este técnico para a direcção da escola, continuando, contudo, a assegurar a direç̧ão da ferramentaria ${ }^{139}$. Rainer Pelikan estivera na escola de formação da Zündapp, antes de ter trabalhado numa empresa suíça de máquinas-ferramentas.

As aulas, com uma frequência inicial de dez alunos, tiveram início em instalações provisórias, próximas da ferramentaria, onde os alunos aprendiam e realizavam um conjunto de exercícios de desbaste, ajustamento, fresagem, etc.. A reestruturação de 1970 também traria alterações no plano de estudos da formação. O número de disciplinas cresce, são chamados dois agentes técnicos para assegurarem as disciplinas de Matemática, Tecnologia e Física e é elaborado o regulamento da Escola de Aprendizes ${ }^{140}$. 
Os cursos de Serralheiro Mecânico, Fresador e Torneiro tinham uma duração de três anos. Eram ministradas as disciplinas de Matemática (com um programa idêntico ao do Curso Industrial), Serralharia, Mecânica, Tratamentos Térmicos, Chaparia, Desenho. Para a disciplina de Português foi contratado um professor do Ensino Primário, o prof. Santos Vítor. Enquanto se aguardava a aprovação do regulamento da escola pela Administração da empresa, o jornal Motonoticia adiantava: «desde já se anuncia a introdução, nos respectivos programas, da disciplina de Português, de que tanto necessitam os nossos rapazes, não só por uma questão de cultura geral, mas até porque um bom conhecimento da língua-mãe é um auxiliar poderoso na aprendizagem e aquisição de conhecimentos» ${ }^{141}$.

Existia também uma disciplina de Educação Física, leccionada com intuitos profilácticos. $\mathrm{O}$ reconhecimento das carências alimentares dos alunos, aliado às exigências físicas das tarefas profissionais, acabou por impor a criação desta disciplina (e de uma cantina), que era assegurada por um trabalhador que fora sargento do Exército. As actividades desta disciplina decorriam numa sala (se chovesse) ou num recinto próprio, ao ar livre, logo pela manhã. Depois do banho, os alunos tomavam o pequeno-almoço e seguiam para a escola.

No primeiro ano, os alunos faziam a sua aprendizagem teórica e prática sempre na sala da formação. No ano seguinte, alguns dias por semana, depois do período da manhã, eram distribuídos por vários sectores da fábrica para a formação prática. No terceiro ano, já trabalhavam numa secção.

Embora muitos desses jovens tivessem ido para outros sectores (como a fundição e a serralharia), normalmente iam para a ferramentaria, que era a secção mais especializada da fábrica. Era ali que se executavam moldes, cortantes, pequenas máquinas, equipamento diverso para simplificar o trabalho, peças para máquinas, etc.

Os critérios de avaliação dos conhecimentos eram definidos pelo perfil exigido para a profissão. Alguns alunos, ou por falta de assiduidade ou por falta de empenho ou capacidade, eram eliminados, podendo ingressar, em alguns casos, na fábrica, em postos de trabalho não qualificados. Os restantes eram «despedidos por falta de aproveitamento», ou «por não possuírem qualidades para a escola», ou ainda «por não terem qualidades de trabalho requeridas» ${ }^{142}$.

Mesmo durante o período de dificuldades de 1967-68, a escola funcionou sempre e cresceu o número de alunos, ainda que se tivesse registado um abrandamento das admissões. A forte redução verificada a partir de 1970 poderá ser explicada pelo facto de alguns alunos da escola irem para outras empresas. A introdução de inovações tecnológicas (como a electroerosão) poderia impor a reestruturação dos conteúdos ministrados, não a eliminação da experiência, mas os elevados custos com a escola dividiam a direcção da empresa. No entanto, foi da escola que a empresa se alimentou em termos técnicos. Mais 
tarde, foram os alunos da Escola de Formação que permitiram introduzir o controlo de qualidade.

\section{GRÁFICO 3}

ENTRADA (E SAÍDA) DE APRENDIZES NA ESCOLA DA FÁBRICA, 1965-1971

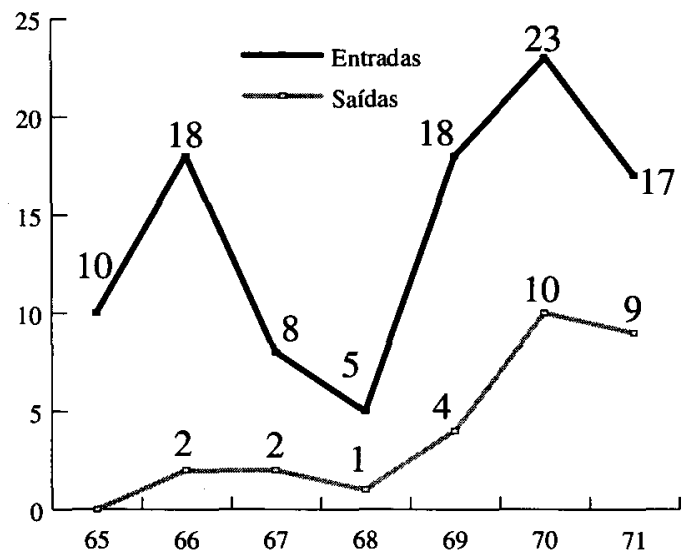

Fonte: AMC, Fichas de Pessoal

Entre as maiores dificuldades com que se debateu a empresa, para lá dos custos de tal empreendimento, da ausência de apoios oficiais e da saída de muitos aprendizes para outras empresas, conta-se a obrigatoriedade do cumprimenté de dois, três e até quatro anos de serviço militar. Muitos desses jovens operários eram incorporados a fim de combaterem em África. A maioria regressava à fábrica, outros não. Para João Francisco do Casal, «esse também foi um problema terrível que a Casal teve». Num balanço final, o empresário considera que a Escola constituía um fardo muito pesado: «não tirámos grande benefício dela, por estas circunstâncias: a escola começou a funcionar em 1965, formou os primeiros operários em 1967-68; entretanto, aqueles jovens atingiam a idade do serviço militar... Só por volta de 1975-76 é que a fábrica começou a obter uma certa compensação do esforço dispendido».

E como olhava o Estado esta escola? João Francisco do Casal é peremptório: «o Estado nunca nos deu absolutamente nada». Durante as visitas à Metalurgia Casal, os altos dignitários do Estado elogiavam a iniciativa, mas não saíam das palavras: «quisemos tornar a escola oficial, queríamos que os rapazes da nossa escola saíssem com um diploma, mas nunca conseguimos. Era-nos dito sempre, 
"vamos ver. Vamos estudar. Façam uma exposição. Isto não se enquadra no sistema português". Nunca conseguimos nada».

Mesmo assim, a empresa tudo fazia para divulgar a natureza do seu projecto de formação profissional. A imprensa regional e o jornal da fábrica divulgavam as cerimónias de «entrega de prémios e diplomas aos alunos da Escola de Aprendizes», para as quais eram convidados diversos representantes do poder local e central ${ }^{143}$.

Em meados do marcante ano de 1970, dá-se uma mudança significativa na formação da mão-de-obra. A par da Escola de Aprendizes, a empresa vai elaborar um programa de formação dos seus trabalhadores. Eram seleccionados todos os operários com idades compreendidas entre os 21 e os 35 anos, com a 4. a classe e o serviço militar cumprido. Havia um curso geral com formação por profissões. Entre aqueles, eram seleccionados 10 a 12 operários para frequentarem um curso de formação, a nível de encarregado ${ }^{144}$.

Desde esse ano, o jornal da empresa vai publicando alguns artigos que testemunham a preocupação da empresa com a formação dos seus recursos humanos, dos trabalhadores não diferenciados aos quadros médios e superiores, subordinada à ideia de que «o capital humano é a principal razão do desenvolvimento e do progresso dos povos como das empresas».

A Formação é apresentada como uma «necessidade premente das empresas que pretendam tornar mais rentável a utilização de máquinas, aumentar a capacidade de produzir, tornando o trabalho mais rápido e menos fatigante. Foi com este espírito que a Administração da Metalurgia Casal criou, recentemente, um serviço de Formação na Empresa. O objectivo próximo da Administração é promover uma Campanha de Formação de Encarregados, que começará brevemente» ${ }^{145}$. No final de 1970, foram realizadas as provas de selecção dos trabalhadores que iriam frequentar o Curso de Encarregados. Dos 150 operários convocados, foram seleccionados 40 , para a frequência da primeira fase do curso; dessa fase transitariam para a segunda apenas 20 . O curso contemplava, portanto, duas vertentes: uma formação básica, que versava conhecimentos de aritmética, geometria, física e mecânica, e uma outra de aperfeiçoamento tecnológico, que visava a aprendizagem de noções relacionadas com a tecnologia utilizada na empresa: tratamentos térmicos, fundição injectada, cunhos e cortantes, soldadura, galvanoplastia e organização $^{146}$. O primeiro decorria numa sala da empresa; o segundo decorria nas diversas secções. Segundo Canaveira Russo, seu orientador, com o curso pretendia-se «formar novos encarregados capazes de responder às exigências imediatas da empresa, no sector da produção», bons conhecedores do seu ofício, mas também excelentes organizadores, capazes de «desenvolver o espírito de equipa» ${ }^{147}$. Os novos encarregados sublinhavam a importância do novo modelo de aprendizagem, contrário ao dos tempos «em que o aprendiz fazia a sua formação junto do oficial» $^{148}$. 
A Metalurgia Casal, «na sua ânsia de expansão e progresso, reconheceu há muito a necessidade imperiosa de se rodear de técnicos e quadros à altura das necessidades hodiernas, não se coibindo de investir a longo prazo na preparação dos seus colaboradores, de que a sua escola de aprendizes é exemplo flagrante» $^{149}$.

A par destas acções de formação, há que referir ainda a presença de vários técnicos em seminários e cursos intensivos realizados em locais vários, sempre a expensas da empresa.

Depois do 25 de Abril de 1974, seria chamado um outro técncio alemão para a reestruturação e refundação da Escola de Aprendizes com a criação, em 1979.09.17, do Centro de Formação Profissional, actualmente em funcionamento. Atendendo à sua especialização e ao seu elevado índice tecnológico, desejando formar uma 'geração nova' de trabalhadores especializados, a Metalurgia Casal requereu a colaboração do Ministério do Trabalho. Assim, depois do auxílio financeiro e da colaboração na formação de monitores que já havia dado a Secretaria de Estado do Emprego / Fundo de Desenvolvimento de Mão-de-Obra, em 1979, foi assinado, em 1980.07.30, um acordo de cooperação entre a empresa e o Ministério do Trabalho e o Ministério da Educação e Ciência, bem antes, portanto, da publicação do Decreto-Lei n. ${ }^{\circ}$ 102/84, de 29 de Março, que estabelece a disciplina jurídica da formação profíssional inicial de jovens em regime de aprendizagem.

\section{CONCLU்SÃO}

Fundada oficialmente nos últimos dias de 1963, a Metalurgia Casal nasce, pois, num contexto muito peculiar da história industrial portuguesa do segundo pós-guerra, entre o encerramento de uma época - assinalado pela aplicação do II Plano de Fomento (1957-1964) - e o início de outra que, apesar das circunstâncias adversas, teve no Plano Intercalar de Fomento (1965-67) e no III Plano de Fomento (1968-73) os principais instrumentos de realização ${ }^{150}$. Se, no seu estudo, se integrar a empresa inicial - a J. Casal (1954-1956) - , poderemos dizer que a Metalurgia Casal é testemunha e agente de «um dos mais profundos processos de mudança estrutural» da história do País ${ }^{151}$.

Após o corte de relações entre a J. Casal e a Zündapp, de 1966 a 1974, a Metalurgia Casal vive os seus «anos loucos», primeiro com uma direcção técnica alemã, depois, desde o importante ano de 1970, com quadros portugueses. Com o "know-how" alemão, João Francisco do Casal introduz em Portugal um novo conceito de empresa, uma forma nova de aliar tecnologia e indústria, no sector das 
dutos novos, diversificados, fiáveis e atractivos, para os padrões de consumo dessa década.

Em 1966 saía o primeiro motor e a primeira "scooter". Seguir-se-iam outros motores, motorizadas e máquinas agrícolas. $\mathrm{Na}$ viragem da década gizavam-se novos empreendimentos, como o de uma fábrica de carburadores, o do fabrico de automóveis e a fábrica de motorizadas, em Luanda. Cinco anos após a saída do primeiro motor, a empresa obtinha autorização ministerial para fabricar um automóvel ${ }^{152}$. Pela sua ambição, o projecto do automóvel Casal é, porventura, o que melhor testemunha a dinâmica de crescimento, a natureza dos estrangulamentos, bem como as fragilidades da conjuntura.

Apesar das muitas dificuldades por que passou nesse período, a empresa adapta-se com facilidade às oscilações dos mercados e às suas necessidades, procura espaço para si e forma a mão-de-obra de que necessita.

Com o 25 de Abril de 1974 veio um tempo marcado por muitas dificuldades, mal disfarçadas pela grande pressão da procura dos primeiros anos (agravamento dos custos de mão-de-obra directa, dos custos fixos, dos encargos sociais, alta permanente das matérias-primas; preços controlados; paragem da fábrica de Angola e resultados negativos no exercício de 1975). Os anos quentes da revolução (que não têm nesta empresa uma expressão significativa) ocorrem numa conjuntura de mudança, caracterizada pela crescente penetração dos mercados pelas marcas japonesas e pela concomitante perda de agressividade dos produtos Casal, aliada ao envelhecimento de alguns meios de produção. A motorizada, como meio de transporte de operários e das populações dos arredores das cidades do Litoral, estava a chegar ao fim. O automóvel ia conquistando um mercado cada vez mais variado, substituindo paulatinamente a motorizada, tal como esta havia substituído a bicicleta.

Essa conjuntura impunha uma renovação tecnológica e organizativa da empresa, uma outra compreensão dos fenómenos envolventes. Depois de um período de grandes esforços nesse sentido, depois da realização de grandes investimentos, vinte anos após a sua fundação, vieram tempos de forte retracção do poder de compra (entre 1980 e 1985), e a Metalurgia Casal passou por grandes dificuldades, agravadas pela escassez de meios financeiros, estando agora a iniciar novo ciclo de criatividade e ascensão.

\section{NOTAS}

1. Cfr. Peter F. Drucker (1994), A Sociedade Pós-Capitalista, especialmente, p. 115-140.

2. Manuela Morgado (1993), «Internacionalização das empresas portuguesas», p. 89. 
3. Expressão de Chistopher Freeman e Carlotta Perez (Cfr. Jean-Jacques Salomon (1989), "Critérios para uma política de Ciência e Tecnologia. De um paradigma a outro», p. 96).

4. Michael E. Porter (1993), A Vantagem Competitiva das Nações, p. 647.

5. Grupo de Lisboa (1994), Limites à Competição, p. 104.

6. Idem, op. cit., p. 106-107.

7. Idem, op. cit., p. 113.

8. Cfr. Sainsaulieu, R. e Segrestin, D. (1986), «Vers une théorie sociologique de l'entreprise», apud Ilona Kovács, «Cientistas sociais nos processos de mudança dos trabalho e das organizaç̃os», p. 240.

9. Sobre as críticas ao fenómeno da competição no mundo actual, veja-se, Grupo de Lisboa, op. cit.

10. Ainda que a obra foque essencialmente a sociedade norte-americana, e se reporte aos últimos anos da década de 80, ver as críticas de Warren Bennis ao mundo empresarial americano (Warren Bennis (1994), Porque é que os líderes não conseguem liderar).

11. «A globalização actual é uma globalização truncada. A triadização constitui uma definição mais adequada à presente situação» (Grupo de Lisboa, op. cit., p. 113).

12. Um bom contributo para a discussão sobre o carácter ideológico dos discursos sobre a empresa é o de António Rafael Amaro (1993), «A cultura organizacional e o(s) poder(es) da história na estruturação da identidade da empresa», p. 97-115.

13. Louis Bergeron «Entreprises», apud José M. Amado Mendes (1992), «A História na Empresa e a Empresa na História», p. 435.

14. Mar Loiseau, «Les modes de communication de l'histoire en entreprise», apud José $\mathbf{M}$. Amado Mendes, «A História na Empresa [...]», p. 436.

15. António Rafael Amaro, op. cit., p. 109.

16. Felix Torres, «Retour vers l'avenir: l'Histoire dans l'entreprise», apud José M. Amado Mendes, p. 436. Tradução da minha responsabilidade.

17. Sobre outros aspectos da relação História/Empresa, veja José M. Amado Mendes, op. cit.

18. Ibidem.

19. Jean-Jacques Salomon (1989), op. cit., p. 92. Veja, também, Alberto Amaral, «A investigação científica e tecnológica e o desenvolvimento do País», p. 83-98.

20. Luís Rosa (1994), Cultura Empresarial. Motivação e liderança. Psicologia das organizações, p. 19.

21. Luís Rosa, op. cit., p. 18.

22. António Rafael Amaro, op. cit., p. 110.

23. Jean-Pierre Anastassopolous, Stratégie, structure, décision, identité - Politique géneral d'entrepri-se, apud António Rafael Amaro, op. cit., p. 110.

24. António Rafael Amaro, op. cit., p. 110-112.

25. Charles Hampden-Turner (1993), Cultura de Empresa. Do círculo vicioso ao círculo virtuoso, p. 19-20.

26. Warren Bennis, op. cit. p. 116.

27. Fernando Rosas (1994), O Estado Novo (1926-1974), p. 450-51 e 462.

28. Francisco Pereira de Moura, apud José Maria Brandão de Brito (1989), A Industrialização portuguesa no Pós-Guerra (1948-1965). O Condicionamento Industrial, p. 174.

144 29. Fernando Rosas, op. cit., p. 457 e 464. 
30. Idem, op. cit., p. 456 e 460-461.

31. Idem, op. cit., p. 430, 450-451 e 464. Cfr. José Maria Brandão de Brito, op. cit.

32. Cfr. Boletim da Direç̧ão Geral dos Serviços Industriais (1955), vol. 7, n. ${ }^{\circ} 349$, 1955.09.07; idem, $\mathrm{n}^{\circ} 351,1955.09 .21$; idem, $\mathrm{n} .^{\circ} 352,1955.09 .28$.

33. Idem (1956), vol. 8, n. ${ }^{\circ} 373,1956.02 .22$. Em 8 de Agosto desse ano é «confirmado o indeferimento, após avocação do respectivo processo» (idem, $n .^{\circ} 397,1956.08 .08$ ).

34. Ibidem. Sublinhado meu.

35. Idem (1962), vol. $14, n^{\circ} 699,1962.05 .23$. $O$ arquivo da actividade desta empresa foi destruído. Além das referências no âmbito do condicionamento industrial, as restantes informações foram concedidas pelo empresário, Sr. João do Casal, ao longo das conversas que mantivemos.

36. João Francisco do Casal. Depoimento gravado. No início dos anos $\mathbf{5 0}$ havia cerca de uma dezena de fabricantes de bicicletas em Portugal; a maioria localizada em Águeda e Porto (Cfr. Associação Industrial Portuguesa e Associação Industrial Portuense, Índice da Produção Industrial Portuguesa, 1955 (Classes 795.1), p. 678).

37. João Francisco do Casal. Depoimento gravado.

38. «A entrevista que faltava», Motonotícia Casal, n. ${ }^{\circ}$ 19, Dezembro 1971, p. 1. Este epis6́dio foi confirmado (e descrito com pormenor), em entrevista gravada.

39. João Francisco do Casal. Depoimento gravado.

40 Cfr. Boletim da Direcção Geral dos Serviços Industriais (1963), vol. 15, n. ${ }^{\circ} 772$.

41. Idem, vol. $15, \mathrm{n} .^{\circ} 775$; idem, $\mathrm{n} .^{\circ} 776$.

42. João Francisco do Casal. Depoimento gravado.

43. «Foi o Governo Português em Janeiro de 1964, por intermédio do Snr. Secretário de Estado da Indústria, que [...] me honrou com o convite para fabricar motoreš em Portugal» (Arquivo Particular de J. F. do Casal (APJFC), Cópia da carta dirigida ao Exmo. Senhor Secretário de Estado do Comércio, em 4 de Outubro de 1965).

44. João Francisco do Casal. Depoimento gravado.

45. APJFC, Memória Descritiva, [1964]. Itálico meu.

46. Ibidem.

47. APJFC, Cópia da Carta do Grémio dos Industriais Metalúrgicos e Metalomecânicos do Sul referente ao pedido de Alvará para Construção de Motores, s/d.

48. Boletim da Direç̧ão Geral dos Serviços Industriais, vol. 16, n. ${ }^{\circ} 790,1964.02 .19$.

49. Idem, vol. 16, $\mathrm{n} .^{\circ} 792,1963.03 .04$. O pedido deu entrada em 1964.02.22.

50. Idem, vol. 16, n. ${ }^{\circ} 804,1964.05 .27$.

51. Arquivo da Metalurgia Casal (AMC), Carta (traduzida) de 1964.05.15.

52. APJFC, Carta da Zündapp dirigida à J. Casal, 1965.09.14.

53. APJFC, Carta ao Exmo. Senhor Secretário de Estado do Comércio, 1965.10.04.

54. AMC, Carta (traduzida), de 1964.07.28.

55. APJFC, Carta ao Exmo. Senhor Secretário de Estado da Indústria, 1965.03.10.

56. Ibidem.

57. Ibidem.

58. Ibidem.

59. APJFC, Carta à Zündapp Werke, 1965.11.09. 
60. APJFC, Carta ao Exmo. Senhor Secretário de Estado da Indústria, 1965.03.10.

61. Cfr. «Inventário de 1967», original do Relatório e Contas de 1968.

62. APJFC, Carta ao Exmo. Senhor Secretário de Estado da Indüstria, 1965.03.10.

63. João Francisco do Casal. Depoimento gravado.

64. Cfr. Secretaria Notarial de Aveiro, $1 .^{\circ}$ Cartório, not. Joaquim T. da Silveira, liv. 159-B, fls. 1-15.

65. Autorização de 1966.10.17, Diário de Governo, III série, n. ${ }^{\circ} 255$, de 1966.11.03.

66. Nos Estatutos pode ler-se que a conversão das acções nominativas em acções ao portador carece de prévia comunicação ao Conselho de Administração, que poderá, no prazo de oito dias, a contar da recepção da comunicação, usar do direito de as adquirir para a sociedade até ao seu valor nominal.

67. Relatório e Contas. 1967.

68. [Original do] Relatório e Contas. 1967.

69. Relatório e Contas. 1968.

70. AMC, Direç̧ão Geral dos Serviços Industriais, Autorizaçâo Ministerial (of. n. ${ }^{\circ}$ 1732). Data de entrada: 1968.06.25; data de despacho: 1968.11.13.

71. Relatório e Contas. 1969.

72. Relatório e Contas. 1970.

73. AMC, Comunicação n. ${ }^{\circ}$ 4/D.A., 1970.05.20.

74. AMC, Comunicação n. ${ }^{\circ} 7,1970.10 .08$; idem, $n .^{\circ} 1 / D . A ., 1971.01 .08$.

75. AMC, Comunicação n. ${ }^{\circ}$ 8/D.A., 1970.08.28, e idem, $n .^{\circ}$ 6/D.A., 1970.10.06.

76. AMC, «Resumo dos assuntos tratados na reunião de 1970.05.19», 1970.05.22.

77. Relatório e Contas. 1971.

78. «O que fomos no passado», Motonotícia Casal, n. ${ }^{\circ} 21$, Fevereiro 1972, p. 1.

79. Ibidem.

80. Cfr. Arquivo da Direcção Regional da Indústria e Energia do Centro (DRIEC), Processo $n .^{\circ} 2 / 1103$, «Memória descritiva», 1973.06.14.

81. Relatório e Contas. 1972.

82. Ibidem.

83. Cfr. Adelino Torres, «Pacto Colonial e industrialização de Angola (anos 60-70)», Análise Social (1983), vol. XIX (77-78-79), p. 1101-1119.

84. Acta n. ${ }^{\circ}$ 14, Livro de Actas do Conselho de Administração da Metalurgia Casal, fl. 8v.

85. Cfr. Acta n. ${ }^{\circ} 15$, idem, fl. $9 \mathrm{v}$.

86. Cfr. AMC, Actas dos Conselho de Administração, Acta n. ${ }^{\circ} 26 / 17,1974.04 .26$, idem, fl. $15 \mathrm{v}$.

87. Cfr. AMC, «Certidão de aumento de capital e alteração parcial do pacto social [...]», 1974.06.21.

88. Cfr. Acta n. ${ }^{\circ} 20 / 14$, idem, fl. 13 , e Acta n. ${ }^{\circ} 23 / 15,1973.07 .31$, idem, fls. 14-14v.

89. Cfr. AMC, «Contrato celebrado entre a Metalurgia Casal e a Fábrica de Bicicletas de Moçambique, SARL», 1973.09.12, art. ${ }^{\circ} .5^{\circ}$.

90. Fernando Rosas, op. cit., p. 465.

91. «O que fomos no passado», Motonotícia Casal, n. ${ }^{\circ} 21$, Fevereiro 1972, p. 1.

146 92. João Francisco do Casal. Depoimento gravado. 
93. Cfr. Motor Ilustrado, vários anos.

94. Cfr. Associação Industrial Portuguesa e Associação Industrial Portuense, Índice da Produção Industrial Portuguesa, 1955 (Classes 793.21), p. 651.

95. Ibidem.

96. «Visita da Imprensa do Distrito à Metalurgia Casal», Litoral, n. ${ }^{\circ} 604,1966.06 .04$, p. 5 , c. 1-2. Veja, também, o Lutador, ano II, n. ${ }^{\circ} 87,1966.06 .03$, p. 7-8.

97. «A Metalurgia Casal», Lutador, n. ${ }^{\circ} 112,1966.12 .09$, p. 2.

98. «Mais uma visita de estudo à Metalurgia Casal», Litoral, n. ${ }^{\circ}$ 597, 1966.04.16, p. 2, c. 2-4.

99. Ibidem.

100. «A Metalurgia Casal», Lutador, n. ${ }^{\circ} 112,1966.12 .09$, p. 2.

101. B. C. «Arménio Saraiva responde», Motonotícia Casal, n. ${ }^{\circ}$ 21, Fevereiro 1972, p. 6.

102. Cfr. Relatório e Contas de 1968.

103. Ibidem.

104. Cfr. «Breve História da Casal», Duas Rodas, II série, n. ${ }^{\circ}$ 5, 1973, p. 18-19.

105. Cfr. Lutador, 1966.12.30, p. 3.

106. «Ainda o Grande Prémio Casal», Lutador, ano V, n. ${ }^{\circ} 246$, 1969.08.08, p. 6.

107. «I Grande Prémio Casal Motocross», Motonotícia, n. ${ }^{\circ}$ 14, Junho 1971, p. 3.

108. «A 'K187 S' vista por técnicos estrangeiros», Motor, 1974.12.24, p. 19. Esse artigo foi enviado à empresa Moto Reparadora, do Lobito.

109. AMC, Eduardo J. C. S. Simão e Atílio Lima Fevereiro, Relatório do comportamento de duas motos Casal 125 cc. M/K 270, 1973.09.17.

110. A. V. F., «Reunião-colóquio »; Motonotícia, n. ${ }^{\circ}$ 3, Março 1970, p. 3.

111. A. C., "A K 260. A primeira moto cem por cento portuguesa», Motonoticia Casal, n. ${ }^{\circ} 23$, Abril 1972, p. 8.

112. Ibidem.

113. Joaquim Barosa R. Lavos; idem, «A Feira de Milão», Motonotícia, n. ${ }^{\circ}$ 2, 1970, p. 2.

114. Idem, «A Feira de Milão», Motonotícia, n. ${ }^{\circ} 2,1970$, p. 2 e 4.

115. Ibidem.

116. Relatório e Contas. 1968.

117. «Breve História da Casal», Duas Rodas, II série, n. ${ }^{\circ} 5,1973$, p. 18.

118. B. C. «Arménio Saraiva responde», Motonotícia Casal, n. ${ }^{\circ}$ 21, Fevereiro 1972, p. 6.

119. Ibidem.

120. Cfr. Lutador, ano V, n. ${ }^{\circ} 246,1969.08 .08$, p. 6.

121. «A entrevista que faltava», Motonotícia Casal, n. ${ }^{\circ} 19$, Dezembro 1971, p. 4.

122. Joaquim Barosa R. Lavos. Depoimento gravado.

123. Cf. «Inauguração da Fábrica de Montagem de automóveis da Ford», Motor, n. ${ }^{\circ}$, 1964.01 .09 , p. 1.

124. $4 .^{\circ}$ Aniversário da morte do Eng. Robert Erich Zipprich. Romagem de saudade e gratidão do pessoal da Metalurgia Casal. Dia 22 de Abril de 1978.

125. AMC, Ordem de Serviço, n. ${ }^{\circ} 3,1970.03 .31$.

126. Ibidem. W. O. Pregitzer este ao serviço da Metalurgia Casal, entre 1969.01.01 e 1970.12.31. 
127. Robert E. Zipprich não comparecera na reunião de 1970.12 .29 .0 pedido de demissão é apreciado em 1971.05.28 (Cfr. Acta . $^{\circ}$ 10/5).

128. AMC, Ordem de Serviço, n. $.^{\circ} 3,1970.03 .31$. Este engenheiro mecânico, contratado em 1972.02.09, estivera na Companhia Portuguesa de Celulose, entre 1965 e 1970.

129. Cfr. Associação Industrial Portuguesa e Associação Industrial Portuense, Índice da Produção Industrial Portuguesa, 1955, p. 497-646 (Classes 70-78).

130. Cfr. Manuel Ferreira Rodrigues, A Escola Industrial e Comercial de Aveiro, 1893-1993 (no prelo).

131. Cfr. A Sedas Nunes et al (1969), «Níveis de instrução na indústria portuguesa», Análise Social, vol. VII, 27-28, p. 645-705.

132. Joaquim Barosa R. Lavos. Depoimento gravado..

133. João Francisco do Casal. Depoimento gravado.

134. Joaquim Barosa R. Lavos. Depoimento gravado.

135. A. V. F., «Reunião-colóquio », Motonotícia, n. ${ }^{\circ} 3,1970$, p. 5 . Veja o n. ${ }^{\circ}$ seguinte.

136. «Sugestões», Motonotícia, n. ${ }^{\circ}$ 3, Junho 1971, p. 4.

137. Natural da Gafanha da Nazaré, fllhavo, José Teixeira da Rocha nasce em 1935. É admitido na Metalurgia Casal em 1965.06.21. Quatro anos depois, em 1969.12.31, abandona a empresa (AMC, Fichas de Pessoal, n. ${ }^{\circ} 135$ ). J. Teixeira da Rocha foi professor da Escola Industrial e Comercial de Aveiro apenas no ano lectivo de 1964-1965 (Ibidem).

138. António Guardado de Almeida tinha o Curso Industrial de Serralheiro Mecânico e fora contra-mestre da Escola Industrial e Comercial da Figueira da Foz, entre 1957 e 1965.

139. Natural de Warnsdorf, Rainer Pelikan nasce em 1942. Em 1965.08.09 é admitido na Metalurgia Casal. A sua demissão verifica-se 1969.12.31 (AMC, Fichas de Pessoal, n. ${ }^{\circ} 162$ ).

140. «Formação profissional de novos encarregados», Motonotícia Casal, $\mathrm{n}^{\circ}{ }^{10}$, Dezembro 1970 , p. 2.

141. «Pela Fábrica», Motonotícia Casal, n. ${ }^{\circ} 8$, Agosto 1970, p. 2.

142. Foi possível arrolar oito casos com esta justificação oficial.

143. Cfr. «Prémios escolares da 'Metalurgia Casal' , Litoral, n. ${ }^{\circ} 779,1969.10 .11$, p. 5 , c. 1.

144. "A Metalurgia Casal adopta a formação», Motonotícia Casal, n. ${ }^{\circ} 8$, Agosto 1970, p. 2 e 4 .

145. Ibidem.

146. «Formação profissional de novos encarregados», Motonotícia Casal, n. ${ }^{\circ}$ 10, Dezembro 1970 , p. 3.

147. «Curso de Formação de Encarregados», Motonotícia Casal, n. ${ }^{\circ} 11$, Fevereiro 1971, p. 2.

148. «Cursos de Formação Profissional na Metalurgia Casal», Motonotícia Casal, n. ${ }^{\circ} 18$, Fev. 1971, p. 4.

149. G. Carvalho «Formação de pessoal», Motonotícia Casal, n. ${ }^{\circ}$ 21, Fevereiro 1972, p. 8.

150. Cfr. Fernando Rosas, op. cit., p. 419-501.

151. Idem, op. cit., p. 419.

152. AMC, Autorização Ministerial, 1968.11.13. 


\section{FONTES E BIBLIOGRAFIA}

Arquivo da Direção Regional da Indústria e Energia do Centro

Processo $n .^{\circ} 2 / 1103$.

\section{Arquivo da Metalurgia Casal}

Autorização ministrial, 1968.11.13.

Comunicações da Direcção Administrativa, n.os 1, 4, 6, 7 e 8 de 1970

Contrato entre a Metalurgia Casal e a Fábrica de Bicicletas de Moçambique, SARL", 1973.09.12.

Direç̧ão Geral dos Serviços Industriais, Autorização Ministerial (of. $\mathrm{n}^{\circ}{ }^{1732}$ ).

Fichas de Pessoal, 1964-1974.

Livro de Actas do Conselho de Administração da Metalurgia Casal, 1967-1974.

Ordem de Serviço, n. ${ }^{\circ} 3,1970.03 .31$.

Relatório do comportamento de duas motos Casal 125 cc. M/K 270, 1973.09.17.

Relatórios e Contas, 1967 a 1975.

Resumos de reuniōes da Direcção Administrativa, 1970.

\section{Arquivo Particular de João Francisco do Casal}

Carta ao Exmo. Senhor Secretário de Estado da Indústria, 1965.03.10.

Carta ao Exmo. Senhor Secretário de Estado do Comércio, 1965.10.04.

Carta do Grémio dos Industriais Metalúrgicos e Metalomecânicos do Sul referente ao pedido de Alvará para Construção de Motores, s/d.

Cartas da Zündapp Werke GmbH, 1964-1965.

Cópias de cartas dirigidas à Zündapp Werke GmbH, 1964-65.

Memória Descritiva s/d.

4. ${ }^{\circ}$ Aniversário da morte do Eng. Robert Erich Zipprich. Romagem de saudade e gratidão do pessoal da Metalurgia Casal. Dia 22 de Abril de 1978.

\section{Arquivo do Registo Civil de Aveiro}

Registos de baptismo, casamento e óbito da família de João Francisco do Casal.

Arquivo da Secretaria Notarial de Aveiro

Notário Joaquim T. da Silveira, livros 121-B e 159-B.

\section{JORNAIS}

Duas Rodas, II série, 1971-1973.

Litoral, 1966-1974.

Lutador, 1964-1969.

Motonoticia Casal, 1970-1972.

Motor, 1971-1974.

Motor Ilustrado, 1954-1964.

\section{OUTROS DOCUMENTOS}

Diário de Governo, III série, n. ${ }^{\circ} 255$, de 1966.11.03.

Associação Industrial Portuguesa e Associação Industrial Portuense, Indice da Produção Industrial Portuguesa, 1955.

Boletim da Direcção Geral dos Serviços Industriais, 1954-1974. 


\section{BIBLIOGRAFIA GERAL}

AMARAL, Alberto (1989), «A investigação científica e tecnológica e o desenvolvimento do País», in Colóquio/Ciências, n. ${ }^{\circ}$ 5, Maio-Agosto de 1989, p. 83-98.

AMARO, António Rafael (1993), «A cultura organizacional e o(s) podere(s) da história na estruturação da identidade da empresa», Gestão e Desenvolvimento, n. ${ }^{\circ}$ 2, p. 97-115.

BENNIS, Warren (1994), Porque é que os líderes não conseguem liderar, Lisboa, Publicaçð̃es D. Quixote, col. «Gestão \& Inovação», série «Gerir hoje», n. ${ }^{\circ} 1$.

BRITO, José Maria Brandão de (1989), A Industrialização portuguesa no Pós-Guerra (1948-1965). O Condicionamento Industrial, Lisboa, Pub. D. Quixote, col. «Universidade Moderna», n. ${ }^{\circ} 90$.

DRUCKER, Peter F. (1993), A Sociedade Pós-Capitalista, Lisboa, Difusão Cultural, col. «Homens \& Empresas».

HAMPDEN-TURNER, Charles (1993), Cultura de Empresa. Do círculo vicioso ao círculo virtuoso, Lisboa, Editorial Presença, col. «Biblioteca de Gestão Moderna», n. ${ }^{\circ} 68$.

KOVÁCS, Ilona (1993), «Cientistas sociais nos processos de mudança do trabalho e das organizações», in M. ${ }^{a}$ Eduarda Gonçalves (coord.), Comunidade Científica e Poder, Lisboa, Edições 70, p. 240-256.

LISBOA, Grupo de (1994), Limites à Competição, Lisboa, Europa-América.

MENDES, José M. Amado (1992), «A História na Empresa e a Empresa na História», Estudos de Homenagem a Jorge Borges de Macedo, Lisboa, INIC, p. 433-443.

MENDES, José M. Amado (1992), «Cultura de Empresa: uma nova dinâmica organizacional», Gestão e Desenvolvimento, $\mathrm{n} .^{\circ} 1$, p. 49-57.

MORGADO, Manuela (1993), «Internacionalização das empresas portuguesas», O Economista, n. ${ }^{\circ}$ 6: Anuário da Economia Portuguesa 1993, p. 88-97.

NUNES, A. Sedas et al (1964), «Níveis de instrução na indústria portuguesa», Análise Social, vol. VII, 27-28, p. 645-705.

PORTER, Michael E. (1993), A Vantagem Competitiva das Nações, Rio de Janeiro, Editora Campus.

RODRIGUES, Manuel Ferreira Rodrigues, A Escola Industrial e Comercial de Aveiro, 1893-1993, (no prelo).

ROSA, Luís (1994), Cultura Empresarial. Motivação e liderança. Psicologia das organizações, Lisboa, Editorial Presença, col. «Biblioteca de Gestão Moderna», n. ${ }^{\circ} 73$.

ROSAS, Fernando (1994), O Estado Novo (1926-1974), in José Mattoso (dir.), História de Portugal, vol. VII, Lisboa, Círculo de Leitores.

SALOMON, Jean-Jacques (1989), «Critérios para uma política de Ciência e Tecnologia. De um paradigma a outro», Colóquio/Ciências. Revista de Cultura Científica, n. ${ }^{\circ} 4$, p. 90-98.

TORRES, Adelino, «Pacto Colonial e industrialização de Angola (anos 60-70)», Análise Social (1983), vol. XIX (77-78-79), p. 1101-1119. 


\section{Agradecimento}

Para a realização deste trabalho foi decisiva a prestimosa colaboração de muitas pessoas. Antes de mais, destaco a enorme solicitude com que o Sr. João do Casal colocou à minha disposição todos os documentos na sua posse e acedeu a conversar comigo por várias vezes, algumas na companhia de seu irmão, Sr. Manuel do Casal, a quem também fico grato. $O$ acesso aos elementos de arquivo de que necessitei e o esclarecimento de inúmeros problemas que as lacunas da documentação colocavam só foi possivel graças à colaboração do administrador da Metalurgia Casal, Sr. Joaquim Barosa Rodrigues Lavos. Muito útil foi a colaboração do Sr. Armando Marques Coutinho, do Sr. José Cardoso de Carvalho, do Sr. José Teixeira da Rocha, e dos responsáveis pelo Centro de Formação Profissional da Casal, Dr. João Cruz e Sr. Eng. Mário Júlio Varela. A D. Maria Aurora e o Sr. José Santos merecem uma referência pela grande simpatia com que satisfizeram sempre os meus pedidos. 